\title{
Humoral- and T-Cell-Specific Immune Responses to SARS-CoV-2 mRNA Vaccination in Patients With MS Using Different Disease-Modifying Therapies
}

Carla Tortorella, MD, PhD, * Alessandra Aiello, PhD, * Claudio Gasperini, MD, PhD, Chiara Agrati, PhD, Concetta Castilletti, PhD, Serena Ruggieri, MD, PhD, Silvia Meschi, PhD, Giulia Matusali, PhD, Francesca Colavita, PhD, Chiara Farroni, PhD, Gilda Cuzzi, MSc, Eleonora Cimini, PhD, Eleonora Tartaglia, MSc, Valentina Vanini, MLT, Luca Prosperini, MD, PhD, Shalom Haggiag, MD, Simona Galgani, MD, Maria Esmeralda Quartuccio, MD, Andrea Salmi, MLT, Federica Repele, MSc, Anna Maria Gerarda Altera, MLT, Flavia Cristofanelli, MSc, Alessandra D'Abramo, MD, Nazario Bevilacqua, MD, Angela Corpolongo, MD, Vincenzo Puro, MD, Francesco Vaia, MD, Maria Rosaria Capobianchi, PhD, Giuseppe Ippolito, MD, Emanuele Nicastri, MD, PhD, and Delia Goletti, MD, PhD, on behalf of the INMI COVID-19 Vaccine Study Group

Neurology ${ }^{\circledR}$ 2022;98:e541-e554. doi:10.1212/WNL.0000000000013108

\section{Abstract}

\section{Background and Objectives}

To evaluate the immune-specific response after full severe acute respiratory syndrome coronavirus 2 (SARS-CoV-2) vaccination of patients with multiple sclerosis (MS) treated with different disease-modifying drugs by the detection of both serologic and T-cell responses.

\section{Methods}

Healthcare workers (HCWs) and patients with MS, having completed the 2-dose schedule of an mRNA-based vaccine against SARS-CoV-2 in the past 2-4 weeks, were enrolled from 2 parallel prospective studies conducted in Rome, Italy, at the National Institute for Infectious diseases Spallanzani-IRCSS and San Camillo Forlanini Hospital. Serologic response was evaluated by quantifying the region-binding domain $(\mathrm{RBD})$ and neutralizing antibodies. Cell-mediated response was analyzed by a whole-blood test quantifying interferon (IFN) $-\gamma$ response to spike peptides. Cells responding to spike stimulation were identified by fluorescence-activated cell sorting analysis.

\section{Results}

We prospectively enrolled 186 vaccinated individuals: 78 HCWs and 108 patients with MS. Twenty-eight patients with MS were treated with IFN- $\beta$, 35 with fingolimod, 20 with cladribine, and 25 with ocrelizumab. A lower anti-RBD antibody response rate was found in patients treated with ocrelizumab $(40 \%, p<0.0001)$ and fingolimod $(85.7 \%, p=0.0023)$ compared to HCWs and patients treated with cladribine or IFN- $\beta$. Anti-RBD antibody median titer was lower in patients treated with ocrelizumab $(p<0.0001)$, fingolimod $(p<0.0001)$, and cladribine $(p=0.010)$ compared to HCWs and IFN- $\beta$-treated patients. Serum neutralizing activity was present in all the HCWs tested and in only a minority of the fingolimod-treated patients (16.6\%). T-cell-specific response was detected in the majority of patients with MS (62\%), albeit with significantly lower IFN- $\gamma$ levels compared to HCWs. The lowest frequency of $\mathrm{T}$-cell response was found in fingolimod-treated patients (14.3\%). T-cell-specific response
Correspondence

Dr. Goletti

delia.goletti@inmi.it
RELATED ARTICLE

Editorial

Reading the " $\mathrm{T}$ " Leaves of COVID-19 Vaccine

Responses in Multiple

Sclerosis

Page 177

\section{MORE ONLINE}

III Class of Evidence Criteria for rating therapeutic and diagnostic studies

NPub.org/coe

\section{COVID-19 Resources}

For the latest articles, invited commentaries, and blogs from physicians around the world NPub.org/COVID19

\footnotetext{
*These authors contributed equally to this work as co-first authors.

From the Department of Neurosciences (C.T., C.G., L.P., S.H., S.G., M.E.Q.), San Camillo-Forlanini Hospital; Translational Research Unit (A.A., C.F., G.C., V.V., A.S., F.R., A.M.G.A., D.G.), Laboratory of Cellular Immunology (C.A., E.C., E.T., Flavia Cristofanelli), Laboratory of Virology (C.C., S.M., G.M., Francesca Colavita, M.R.C.), UOS Professioni Sanitarie Tecniche (V.V.), Clinical Division of Infectious Diseases (A.D.A., N.B., A.C., E.N.), UOC Emerging Infections and CRAIDS (V.P.), Health Direction (F.V.), and Scientific Direction (G.I.), National Institute for Infectious Diseases Lazzaro Spallanzani-IRCCS; Department of Human Neurosciences (S.R.), Sapienza University of Rome; and Neuroimmunology Unit (S.R.), IRCSS Fondazione Santa Lucia, Rome, Italy.

Go to Neurology.org/N for full disclosures. Funding information and disclosures deemed relevant by the authors, if any, are provided at the end of the article.

INMI COVID-19 Vaccine Study Group coinvestigators are listed in the appendix at the end of the article.

The Article Processing Charge was funded by National Institute for Infectious Diseases-IRCCS L. Spallanzani.

This is an open-access article distributed under the terms of the Creative Commons Attribution-Non Commercial-No Derivatives License 4.0 (CCBY-NC-ND), where it is permissible to download and share the work provided it is properly cited. The work cannot be changed in any way or used commercially without permission from the journal.
} 


\section{Glossary}

COVID-19 = coronavirus disease 2019; CPE = cytopathic effect; DMT = disease-modifying treatment; FBS = fetal bovine serum; HCW = health care worker; IFN = interferon; IgG = immunoglobulin G; INMI = National Institute for Infectious Diseases; IQR = interquartile range; PBMC = peripheral blood mononuclear cell; RBD = region-binding domain; SARS-CoV$2=$ severe acute respiratory syndrome coronavirus 2 .

correlated with lymphocyte count and anti-RBD antibody titer $(\rho=0.554, p<0.0001$ and $\rho=0.255, p=0.0078$ respectively $)$. IFN- $\gamma$ T-cell response was mediated by both $\mathrm{CD} 4^{+}$and $\mathrm{CD} 8^{+} \mathrm{T}$ cells.

\section{Discussion}

mRNA vaccines induce both humoral and cell-mediated specific immune responses against spike peptides in all HCWs and in the majority of patients with MS. These results carry relevant implications for managing vaccinations, suggesting promoting vaccination in all treated patients with MS.

\section{Classification of Evidence}

This study provides Class III data that SARS-CoV-2 mRNA vaccination induces both humoral and cell-mediated specific immune responses against viral spike proteins in a majority of patients with MS.

Multiple sclerosis (MS) is an inflammatory autoimmune disease of the CNS and is a leading cause of disability in young adults ${ }^{1}$ in Western countries. Most people with MS are treated with immunomodulatory or immunosuppressive medications, which might increase the risk of opportunistic infections, infectionrelated hospitalization, and infection-related mortality rates. ${ }^{2-4}$

The coronavirus disease 2019 (COVID-19) pandemic caused by severe acute respiratory syndrome coronavirus 2 (SARSCoV-2) has emerged as a human-to-human transmissible disease with a severe global health impact ${ }^{5}$ and difficult clinical management. ${ }^{6,7}$

Large-scale vaccination is the single most effective public health measure for controlling the COVID-19 pandemic and a global effort to develop and distribute an effective vaccine produced several effective options. Several data are now available about the efficacy of the mRNA platform vaccines, namely BNT162b2 and mRNA-1273 vaccines, in inducing strong antibody and cell-mediated immune responses in naive healthy individuals. ${ }^{8-12}$ The ability of vaccines to induce a coordinated induction of both humoral- and cell-mediated arms is fundamental for a more effective fighting of SARSCoV-2 infection ${ }^{13,14}$; this is particularly crucial in people with MS treated with immunotherapy targeting pathogenetic inflammatory processes. ${ }^{15,16}$

Disease-modifying treatments (DMTs) used in MS act at different levels of the immune system. Based on their mechanism of action, they can be divided into: (1) immunomodulators: interferon (IFN) $-\beta$, glatiramer acetate, dimethyl fumarate, and teriflunomide; (2) cell trafficking alteration molecules like S1P receptor modulators (i.e., fingolimod) and $\alpha 4$-integrin antibody (natalizumab); (3) depletive drugs (ocrelizumab, an antiCD20 antibody; cladribine, a purine analog that interferes with
DNA synthesis inducing a prolonged lymphocyte depletion; and alemtuzumab, an anti-CD52 antibody).

The overall effects of these DMTs in affecting the humoral and cell-mediated immune responses to SARS-CoV-2 vaccine is unknown. Preliminary data have been published suggesting that the antibody response to BNT162b2 vaccine is impaired in people with MS treated with fingolimod and ocrelizumab, whereas it is preserved in those treated with cladribine. ${ }^{17-19}$ More recently, Guerrieri et al. ${ }^{20}$ in a real-word study on 32 people with MS have shown a higher frequency of the humoral response $(62.5 \%)$ in patients treated with fingolimod. These data are essential for health decision and need to be confirmed and supplemented by the evaluation of the T-cell-specific response.

The aim of this study was to evaluate the anti-region-binding domain (RBD) neutralizing antibodies and spike (S)-specific $\mathrm{T}$-cell response after the full SARS-CoV-2 vaccination of patients with MS treated with different DMTs.

\section{Methods}

\section{Standard Protocol Approvals, Registrations, and Patient Consents}

Human study protocols were approved by the Lazzaro Spallanzani National Institute for Infectious Diseases (INMI) Ethical Committee (approvals 297/2021 and 319/2021). The study protocols followed the ethics principles for human experimentation in agreement with the Declaration of Helsinki. Written informed consent was obtained from all participants.

\section{Study Population}

Participants were enrolled from 2 parallel prospective studies conducted at the INMI Lazzaro Spallanzani. In detail, the studies evaluated the immune response to SARS-CoV-2 
vaccination in both health care workers (HCWs) enrolled at INMI and in patients with MS enrolled at the MS Centre of the Department of Neurosciences of San Camillo Forlanini Hospital (Rome, Italy).

\section{Patients With MS}

A total of 108 participants were enrolled. Inclusion criteria for the enrollment of patients with MS were (1) diagnosis of MS

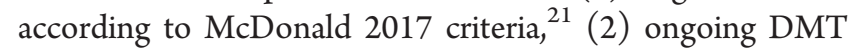
treatment with IFN- $\beta$, fingolimod, ocrelizumab, or cladribine for at least 6 months before study entry, and (3) completed vaccination cycle (both doses) of an mRNA vaccine within the previous 2-4 weeks. In patients undergoing pulsed therapy (ocrelizumab and cladribine), the timing of vaccination after the last DMT administration was scheduled following the recommendation of both the Italian and European Academy of Neurology for COVID-19 vaccination. In particular, in patients with MS, the drugs were provided with a delay of 3 months for ocrelizumab and of at least 4 weeks for cladribine. The therapies with IFN- $\beta$ and fingolimod were not interrupted when vaccination was scheduled. ${ }^{22}$ Blood tests and lymphocyte count were performed within 1 week from the time when the samples were taken for the immune-based assays. Percentage and absolute count of $\mathrm{CD} 19^{+} \mathrm{B}$ cells and serum immunoglobulin G (IgG) levels were collected in patients treated with ocrelizumab within 1 month from the study enrollment.

\section{Health Care Workers}

A convenient sample of $78 \mathrm{HCWs}$ from the cohort of vaccinated HCWs at INMI Lazzaro Spallanzani was included as healthy control group. ${ }^{12,23}$ Blood sampling and handling were performed following a standardized written protocol. Blood samples from all patients with MS were collected at the MS Center of San Camillo Forlanini Hospital, transported to INMI, and processed within 2 hours from collection. The same researchers' group at INMI processed all HCW samples.

\section{Peptide Pools for the T-Cell-Based Tests}

SARS-CoV-2 PepTivator Peptide Pools (Miltenyi Biotec) covering the sequence of SARS-CoV-2 spike protein (PepTivator SARS-CoV-2 Prot_S1, Prot_S, and Prot_S+) were used. $^{24-26}$ The PepTivator Peptide Pools are constituted by peptides of 15 amino acid length with 11 amino acid overlap.

\section{IFN-y Whole Blood Assay}

Whole blood $(600 \mu \mathrm{L})$ was stimulated with SARS-CoV-2 spike peptide pool in a 48-well flat-bottom plate according to the concentrations reported ${ }^{24}$ and incubated at $37^{\circ} \mathrm{C}(5 \%$ $\mathrm{CO}_{2}$ ). Plasma was harvested after 20-24 hours of stimulation and stored at $-80^{\circ} \mathrm{C}$ until use. IFN- $\gamma$ levels were quantified in the plasma samples using an automatic ELISA (ELLA, Protein Simple). IFN- $\gamma$ values of the stimulated samples were subtracted from the unstimulated control. The detection limit of this assay is $0.17 \mathrm{pg} / \mathrm{mL}$.

\section{Peripheral Blood Mononuclear Cells and in Vitro Stimulation}

Peripheral blood mononuclear cells (PBMCs) from a small subset of the vaccinated individuals ( 8 patients with MS and $7 \mathrm{HCWs}$ ) were isolated on density gradient centrifugation (SepMate-50 cat\#85460 or SepMate-15 cat\#85420, StemCell Technologies) according to manufacturer's procedure. The $7 \mathrm{HCWs}$, used as control group, were employed as controls in another publication. ${ }^{27}$ All samples were frozen in heat-inactivated fetal bovine serum (FBS; Euroclone SpA) with $10 \%$ DMSO and stored in liquid nitrogen. PBMCs were thawed, counted, assessed for viability, and rested for $2-4$ hours at $37^{\circ} \mathrm{C}$ in $\mathrm{RPMI}+10 \% \mathrm{FBS}$ prior to further use. Complete medium was freshly prepared as follows: RPMI1640, 10\% FBS, 1\% L-glutamine, and $1 \%$ penicillin/ streptomycin (Euroclone $\mathrm{SpA}$ ). Cells were seeded at a concentration of $2.5 \times 10^{6}$ cells $/ \mathrm{mL}$ in a 96-multiwell flatbottom plate (COSTAR; Sigma Aldrich) and stimulated with spike peptide pool at $1 \mu \mathrm{g} / \mathrm{mL}$ or staphylococcal enterotoxin B (SEB) at $200 \mathrm{ng} / \mathrm{mL}$, as a positive control. AntiCD28 and anti-CD49d monoclonal antibodies (BD Biosciences) were added at $2 \mu \mathrm{g} / \mathrm{mL}$ to costimulate cells. After 1 hour of incubation at $37^{\circ} \mathrm{C}\left(5 \% \mathrm{CO}_{2}\right), 1 \mu \mathrm{L} / \mathrm{mL}$ of Golgi Plug (BD Biosciences) was added to cell cultures to inhibit cytokine secretion. Following an incubation of 16-24 hours, cells were stained as described below.

\section{T-Cell Subpopulations and Intracellular IFN-y Detection}

PBMCs were stained with an appropriate combination of fluorochrome-conjugated antibodies prepared in Brilliant Stain Buffer (BD Biosciences). Cytofix/Cytoperm solution kit (BD Biosciences) was used for intracellular staining of IFN- $\gamma$, according to manufacturer's instructions (see eTable 1, links. lww.com/WNL/B668 for a complete list of antibodies and reagents). Dead cells were excluded from the analysis by side/ forward scatter gating and then by Fixable Viability stain 700 (BD Biosciences). At least 100,000 gated events on living cells were analyzed for each sample, whenever possible. Samples were acquired on a BD Lyric (BD Biosciences) cytometer. Data were analyzed with FlowJo software, version 10 (Tree Star). Cytokine background was subtracted to the stimulated conditions. The T-cell response was considered positive when SARS-CoV-2 spike stimulated PBMCs contained at least twofold higher frequencies of $\mathrm{CD}^{+}$or $\mathrm{CD}^{+} \mathrm{T}$ cells compared to the unstimulated control and at least 10 events were present in the IFN- $\gamma$ gate. $^{28}$

\section{Anti-SARS-CoV-2-Specific IgG Evaluation}

Humoral response to vaccination was assessed by quantifying the anti-nucleoprotein IgG and the anti-RBD IgG (Architect i2000sr; Abbott Diagnostics). Anti-N-IgG were expressed as arbitrary units $/ \mathrm{mL}$ and values $\geq 1.4$ were considered positive. Anti-RBD-IgG were expressed as binding arbitrary units $/ \mathrm{mL}$ and values $\geq 7.1$ were considered positive. 


\section{Microneutralization Assay}

Neutralizing antibodies to SARS-CoV-2 were assessed by a microneutralization assay with live SARS-CoV-2 virus (strain 2019-nCoV/Italy-INMI1; GISAID accession ID: EPI_ISL_ 412974). The assay has been described in detail $^{29}$ and is based on inhibition of Vero E6 cells infection by serum dilution curves, with cytopathic effect (CPE) determination at 48 hours postinfection. Briefly, heat-inactivated and titrated sera (duplicate 2-fold serial dilutions, starting dilution 1:10) were mixed with equal volumes of $100 \mathrm{TCID}_{50}$ SARS-CoV-2 and incubated at $37^{\circ} \mathrm{C}, 5 \% \mathrm{CO}_{2}$ for 30 minutes. Subsequently, 96well tissue culture plates with subconfluent Vero E6 cell monolayers were infected with $100 \mu \mathrm{L} /$ well of virus-serum mixtures and incubated at $37^{\circ} \mathrm{C}$ and $5 \% \mathrm{CO}_{2}$. To standardize the interassay procedures, positive control samples showing high (1:160) and low (1:40) neutralizing activity were included in each MNA session. After 48 hours, microplates were observed by light microscope for the presence of CPE and then stained with crystal violet solution containing $2 \%$ formaldehyde. Cell viability was measured by photometer at 595 nm (Synergy HTX Multi-Mode Microplate Reader, BioTek). The highest serum dilution inhibiting at least $90 \%$ of the CPE was indicated as the neutralization titer and expressed as the reciprocal of serum dilution $\left(\mathrm{MNA}_{90}\right)$.

\section{Statistical Analysis}

Data were analyzed using Graph Pad (GraphPad Prism 8 XML Project). Categorical variables were reported as count and proportion; continuous variables, including IFN- $\gamma$ levels and anti-RBD, anti-N, and $\mathrm{MNA}_{90}$ titers, were reported as median and interquartile range (IQR). All data were investigated by nonparametric statistical inference tests. The Kruskal-Wallis test was used for between-group comparisons, Mann-Whitney $U$ test with Bonferroni correction for pairwise comparisons, and $\chi^{2}$ test for categorical variables. Correlations of demographic, clinical, and laboratory variables with serologic and spike-specific T-response in mRNA-vaccinated individuals, as well as between-assay correlations, were assessed by nonparametric Spearman rank test before and after multivariable adjustment. Spearman $\rho>0.7$ was considered high correlation, $0.7<\rho>0.5$ moderate correlation, and $\rho<0.5$ low correlation.

Two-tailed $p$ values $<0.05$ were considered significant, with except for subgroup analyses by type of MS-specific treatment, where a correction for multiplicity was applied according to Bonferroni method, yielding a significant 2-tailed $p$ value threshold of $0.0125(\alpha / 4)$.

\section{Results}

\section{Demographic and Clinical Characteristics of the Enrolled Participants}

We prospectively enrolled 186 vaccinated participants: 108 patients with MS and 78 HCWs. Demographic and clinical data were collected at enrollment (Table 1). No significant
Table 1 Demographic and Clinical Characteristics of the 186 Enrolled Participants

\begin{tabular}{|c|c|c|c|}
\hline Characteristics & $\begin{array}{l}\text { Patients } \\
\text { with MS }\end{array}$ & $\begin{array}{l}\text { Health care } \\
\text { workers }\end{array}$ & $p$ Value \\
\hline Total & $108(58.1)$ & 78 (41.9) & \\
\hline Age, y & 47 (39-54) & $44(33-53)$ & $0.098^{\mathrm{a}}$ \\
\hline Male & $34(31.5)$ & $20(25.6)$ & $0.408^{c}$ \\
\hline \multicolumn{4}{|l|}{ Origin } \\
\hline Western Europe & $105(97.2)$ & $76(97.4)$ & $0.661^{c}$ \\
\hline Eastern Europe & $2(1.9)$ & $2(2.6)$ & \\
\hline South America & $1(0.9)$ & $0(0)$ & \\
\hline BMI, $\mathrm{kg} / \mathrm{m}^{2}$ & $23.2(20.9-26.5)$ & - & \\
\hline MS duration, y & $13(7-20)$ & - & \\
\hline \multicolumn{4}{|l|}{ MS course } \\
\hline Relapsing-remitting & $98(90.7)$ & - & \\
\hline Primary progressive & $10(9.3)$ & - & \\
\hline EDSS score & $2.0(1.0-3.5)$ & - & \\
\hline \multicolumn{4}{|l|}{ MS treatment } \\
\hline Ocrelizumab & $25(23.2)$ & - & \\
\hline Fingolimod & 35 (32.4) & - & \\
\hline Cladribine & $20(18.5)$ & - & \\
\hline IFN- $\beta$ & $28(25.9)$ & - & \\
\hline $\begin{array}{l}\text { Lymphocytes count } \\
\text { available }\end{array}$ & $87(80.5)$ & $0(0)$ & \\
\hline \multicolumn{4}{|c|}{$\begin{array}{l}\text { Lymphocytes count, } n(\%) \\
\text { median } \times 10 /^{3} \mu \mathrm{L}(\mathrm{IQR})\end{array}$} \\
\hline Ocrelizumab & $\begin{array}{l}25(28.7) ; 1.46 \\
(1.27-1.86)\end{array}$ & - & $<0.0001^{b}$ \\
\hline Fingolimod & $\begin{array}{l}34(39.1) ; 0.66 \\
(0.57-0.95)\end{array}$ & - & \\
\hline Cladribine & $\begin{array}{l}20(23) ; 1.11 \\
(0.87-1.47)\end{array}$ & - & \\
\hline IFN- $\beta$ & $\begin{array}{l}8(9.2) ; 1.60 \\
(1.42-1.99)\end{array}$ & - & \\
\hline
\end{tabular}

Abbreviations: $\mathrm{BMI}=$ body mass index; EDSS = Expanded Disability Status Scale; IFN = interferon; IQR = interquartile range; MS = multiple sclerosis. Values are $\mathrm{n}(\%)$ or median (IQR).

a Mann-Whitney U statistic test.

${ }^{\mathrm{b}}$ Kruskal-Wallis test performed only on patients with MS.

${ }^{c} \chi^{2}$ test.

differences were found regarding age, sex, or country of origin between the 2 groups.

Twenty-eight patients with MS were treated with IFN- $\beta$, 35 with fingolimod, 20 with cladribine, and 25 with ocrelizumab. The median treatment duration at the first vaccine dose was 8.9 years (IQR 6.9-13.5) for IFN- $\beta$, 6.5 years (IQR 3.6-8.1) for fingolimod, and 1.7 years (IQR 1.1-2.3) for ocrelizumab. 
The median time elapsed from the first administration of cladribine to the first vaccine dose was 1.7 years (IQR $1.2-2.0)$; 16 out of 20 patients (80\%) completed the second year treatment cycle. The median time elapsed since the last drug assumption was 8.9 months (IQR 7.7-12.7) for cladribine and 3.8 months (IQR 2.8-4.3) for ocrelizumab.

HCWs as well as 103 patients with MS received the BNT162b2 vaccine; 5 patients with MS received the mRNA1273 vaccine. The median time elapsed from the second vaccine dose and the blood sample collection was 23 days (IQR 21-26), without any difference across treatment subgroups.

As expected, lymphocyte count at the time of immunebased assays sampling was significantly decreased in patients treated with fingolimod compared to those treated with other DMTs $(p<0.0001)$. Patients treated with ocrelizumab showed a very low percentage of $\mathrm{CD} 19^{+}$ $\mathrm{B}$ cells (median 0.04\%; IQR 0.03\%-0.09\%; normal range 6\%-20\%) and CD $19^{+}$absolute count (median 0.89 cells/ $\mu \mathrm{L}$; IQR $0.38-1.67$ cells $/ \mu \mathrm{L}$; normal range $90-520$ cells $/ \mu \mathrm{L}$, respectively). In these patients, the median IgG level, obtained within 1 month from the study enrollment, was $900 \mathrm{mg} / \mathrm{dL}$ (IQR 829-1,100 mg/dL), except for 2 patients with IgG levels below the lowest limit of the normal range $(700-1,600 \mathrm{mg} / \mathrm{dL})$. No correlation was found between IgG levels and anti-RBD titer $\left(r_{s}=0.26, p=0.19\right)$.

Most of the enrolled HCWs were healthy ( $\mathrm{n}=64[82 \%])$; 93.5\% $(n=73)$ were untreated, $4 \%(n=3)$ were treated with corticosteroids for a history of allergic diseases, whereas no clinical data were available for $2.5 \%(n=2)$ of the HCWs (see eTable 2, links.lww.com/WNL/B668).

\section{Serologic-Specific Response in Vaccinated Individuals}

Anti-N antibodies were undetectable in both patients with MS and HCWs, confirming the absence of SARS-CoV-2 natural infection in the study population (eFigure 1, links.lww.com/ $\mathrm{WNL} / \mathrm{B} 668$ ).

A detectable anti-RBD antibody response was observed in all HCWs (100\%). The majority of patients with MS $(n=87$ [80.5\%]) showed anti-RBD antibody response, although the percentage of seropositive patients and the quantitative specific response varied according to the ongoing DMTs. A detectable anti-RBD response was found in 10/25 (40\%) patients treated with ocrelizumab, in 30/35 (85.7\%) patients treated with fingolimod, in $27 / 28$ (96.4\%) patients treated with IFN- $\beta$, and in all patients (100\%) treated with cladribine (Table 2). Ocrelizumab- and fingolimod-treated patients showed lower response rates compared to HCWs $(p<0.0001$ and $p=0.0023$, respectively).

The anti-RBD antibody median titer was significantly lower in patients with MS treated with ocrelizumab $(p<0.0001)$, fingolimod $(p<0.0001)$, and cladribine $(p=0.01)$ compared to HCWs. No differences in the serologic median titer in comparison to HCWs were found in patients treated with IFN- $\beta(p=0.359)$ (Figure 1A). In ocrelizumab-treated patients, a longer treatment duration was significantly associated with reduced anti-RBD antibody titers $(\rho=-0.529, p=$ 0.007 ), whereas age, BMI, and disease duration did not show any effect. Furthermore, none of these variables was associated with reduced anti-RBD antibody titers in patients treated with fingolimod or cladribine (Table 3).

In patients treated with cladribine and ocrelizumab, no correlation was found between the anti-RBD antibody titer and the time elapsed since the last treatment cycle $(\rho=0.111, p=$ 0.640 and $\rho=-0.014, p=0.946$, respectively). Moreover, in those treated with ocrelizumab, the anti-RBD titer did not correlate with serum IgG levels $(p=0.19)$.

\section{IFN-y T-Cell-Specific Response in Vaccinated Individuals}

All HCWs showed an IFN- $\gamma$ spike-specific T-cell response (78/ $78[100 \%])$ as compared with $67(62 \%)$ in the MS cohort. Different proportions of T-cell-specific responses were found among patients with MS: $92 \%$ (23/25 patients) in the ocrelizumab-treated group, $89.3 \%$ (25/28 patients) in the IFN$\beta$-treated group, $70 \%$ (14/20 patients) in the cladribine-treated group, and $14.3 \%$ (5/35 patients) in the fingolimod-treated group $(p<0.0001)$. Cladribine- and fingolimod-treated patient response rates were significantly lower compared to HCWs $(p<0.0001)$ (Table 2).

The IFN- $\gamma$ T-cell-specific response levels were significantly lower in MS-vaccinated individuals undergoing any DMTs than in HCWs $(p<0.0001)$ (Table 2 and Figure 1B). In patients with MS, sex, age, BMI, disease duration, and DMT treatment duration at the time of vaccination did not affect the IFN- $\gamma$ T-cell-specific response. No association was found between the IFN- $\gamma$ T-cell-specific response and the abovementioned variables in the single MS-treated group (Table 3).

In patients treated with cladribine and ocrelizumab, the IFN- $\gamma$ T-cell-specific response was not related to time elapsed since the last treatment cycle $(\rho=-0.353, p=0.127$ and $\rho=-0.271$; $p=0.189$, respectively).

\section{IFN-y Response Is Mediated by CD4 ${ }^{+} \mathrm{T}$ Cells and CD $8^{+}$T Cells}

To evaluate whether the IFN- $\gamma$ T-cell-specific response was due to the $\mathrm{CD}^{+}$or $\mathrm{CD} 8^{+} \mathrm{T}$-cell subset, we evaluated the IFN$\gamma$-specific T-cell frequency in stimulated PBMCs of 8 patients with MS (4 treated with IFN- $\beta$ and 4 with cladribine) and 7 HCWs. We selected IFN- $\beta$ - and cladribine-treated patients since they showed, as reported in Figure 1, good specific antibody and T-cell responses. $\mathrm{T}$ cells were gated as described in eFigure 2, links.lww.com/WNL/B668. In HCWs, IFN- $\gamma-\mathrm{T}$ cell-specific response was mediated by $\mathrm{CD}^{+}$(Figure $2 \mathrm{~A}$ ) and $\mathrm{CD}^{+} \mathrm{T}$ cells (Figure 2B) with a different magnitude of 
Table 2 Serologic and T-Cell-Specific Responses

\begin{tabular}{|c|c|c|c|c|}
\hline Characteristics & Patients with MS & Health care workers & $p$ Value & \\
\hline Total & $108(58.1)$ & $78(41.9)$ & & \\
\hline \multicolumn{5}{|l|}{ Antibody response } \\
\hline \multicolumn{5}{|l|}{ Qualitative response } \\
\hline Anti-RBD Abs responders & $87(80.5)$ & $78(100)$ & $<0.0001^{a}$ & \\
\hline \multicolumn{5}{|c|}{ Anti-RBD Abs responders within the subgroups } \\
\hline Ocrelizumab & $10 / 25(40)$ & - & $<0.0001^{a}$ & $<0.0001^{a, d}$ \\
\hline Fingolimod & $30 / 35(85.7)$ & - & & $0.0023^{\mathrm{a}, \mathrm{d}}$ \\
\hline Cladribine & $20 / 20(100)$ & - & & $>0.9999^{a}$ \\
\hline IFN- $\beta$ & $27 / 28(96.4)$ & - & & $0.264^{\mathrm{a}}$ \\
\hline \multicolumn{5}{|l|}{ Quantitative response } \\
\hline Anti-RBD Abs, BAU/mL & $284.5(18.8-1,497)$ & $2,395(1,445-4,089)$ & $<0.0001^{\text {b }}$ & \\
\hline Ocrelizumab & $3.40(0.45-21.85)$ & - & $<0.0001^{\mathrm{c}}$ & $<0.0001^{b, c}$ \\
\hline Fingolimod & $48(20.60-166.70)$ & - & & $<0.0001^{b, c}$ \\
\hline Cladribine & $1,360(967.5-2,177)$ & - & & $0.010^{\mathrm{b}, \mathrm{d}}$ \\
\hline IFN- $\beta$ & $2,164(1,047-3,504)$ & & & $0.359^{b}$ \\
\hline
\end{tabular}

Spike-specific IFN-y T-cell response

Qualitative response

Anti-spike responders

67 (62)

$78(100)$

$<0.0001^{\text {a }}$

Anti-spike responders within the subgroups

\begin{tabular}{|c|c|c|c|c|}
\hline Ocrelizumab & $23 / 25(92)$ & - & $<0.0001^{a}$ & $0.057^{\mathrm{a}}$ \\
\hline Fingolimod & 5/35 (14.3) & - & & $<0.0001^{a, d}$ \\
\hline Cladribine & $14 / 20(70)$ & - & & $<0.0001^{a, d}$ \\
\hline IFN- $\beta$ & $25 / 28(89.3)$ & - & & $0.017^{a}$ \\
\hline \multicolumn{5}{|l|}{ Quantitative response } \\
\hline Anti-spike IFN-y, pg/mL & $53.09(3.47-135.3)$ & $343.8(167-703)$ & $<0.0001^{\mathrm{b}}$ & \\
\hline Ocrelizumab & $128.9(49.5-268.7)$ & - & $<0.0001^{c}$ & $<0.0001^{b, d}$ \\
\hline Fingolimod & $1.75(0.18-5.3)$ & - & & $<0.0001^{b, c}$ \\
\hline Cladribine & $60(14.6-138.9)$ & - & & $<0.0001^{b, d}$ \\
\hline IFN- $\beta$ & $84(51.2-385.6)$ & - & & $0.0004^{b, d}$ \\
\hline
\end{tabular}

Abbreviations: Abs = antibodies; BAU = binding arbitrary unit; IFN = interferon; IQR = interquartile range; MS = multiple sclerosis; RBD = receptor-binding domain.

Values are $\mathrm{n}(\%)$ or median (IQR).

${ }^{a}$ Chi-square test.

b Mann-Whitney $U$ statistic test.

c Kruskal-Wallis.

d Significant after multiplicity correction by the Bonferroni method $(\alpha / 4=0.0125)$.

response (median CD4: $0.279 \%$, IQR $0.193-0.427$ vs median CD8: 0.058\%, IQR 0.00-0.140) (Figure 2C). In patients with MS, the IFN- $\gamma$ response was mediated only by $\mathrm{CD}^{+} \mathrm{T}$ cells (IFN- $\beta$ : median $0.16 \%$, IQR 0.109-0.192 and cladribine: median $0.13 \%$, IQR $0.117-0.163$ ) (Figure 2C). The frequency of antigen-specific $\mathrm{CD} 4^{+}$or $\mathrm{CD} 8^{+} \mathrm{T}$ cells was lower in patients with MS compared to HCWs, although this difference was not significant (Figure 2C). A positive T-cell response to SEB, used as a positive control, was found in all subjects, and the percentages of $\mathrm{CD}^{+}, \mathrm{CD}^{+}$, and $\mathrm{CD}^{+} \mathrm{T}$ cells were comparable between HCWs and patients with MS (data not shown). 

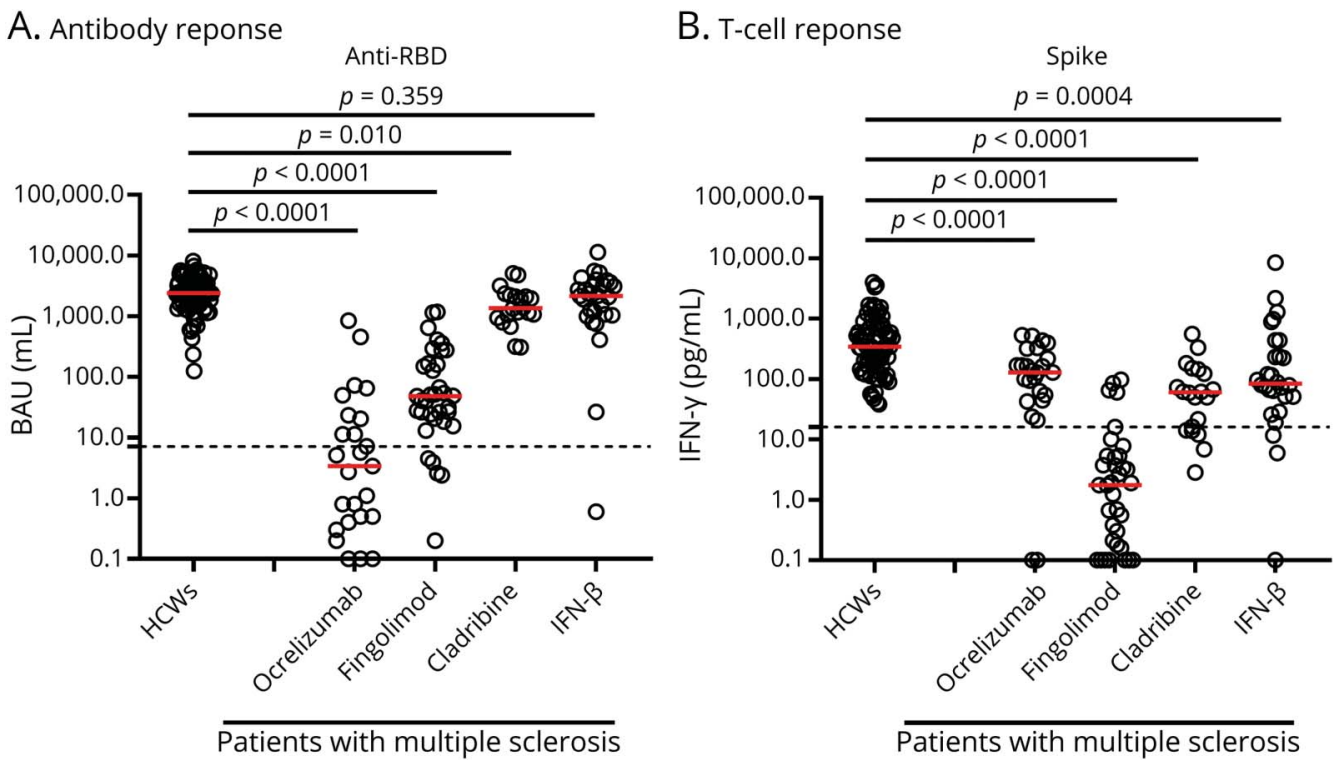

(A) Evaluation of antibody (Ab) response in 78 health care workers (HCWs) and 108 patients with multiple sclerosis stratified according to drug treatment in 4 groups: ocrelizumab $(n=25)$, fingolimod $(n=35)$, cladribine $(n=20)$, and interferon (IFN)- $\beta(n=28)$. Severe acute respiratory syndrome coronavirus 2 (SARSCoV-2)-specific anti-receptor-binding domain (RBD) Abs were quantified in plasma or sera samples. Anti-RBD immunoglobulin G (IgG) was expressed as binding arbitrary units (BAU)/mL and values $\geq 7.1$ were considered positive. (B) Evaluation of IFN-y response to spike antigen. IFN-y was measured by automatic ELISA in plasma harvested from stimulated whole blood samples and shown as median after subtracting the background. Dashed lines identify the cutoff of each test (spike $16 \mathrm{pg} / \mathrm{mL}$ and anti-RBD 7.1 BAU/mL). Each black dot represents 1 sample. The red horizontal lines represent the median; statistical analysis was performed using the Mann-Whitney test and $p$ value was considered significant if $\leq 0.0125$.

\section{Correlation Between Anti-RBD Antibody Titer, IFN-y T-Cell-Specific Response, and Lymphocyte Count}

A significant slight correlation was observed in patients with MS between anti-RBD antibody titer and IFN- $\gamma$-spikespecific T-cell response $(\rho=0.255, p=0.0078)$ (Figure $3 \mathrm{~A}$ ), persisting after adjusting for sex, age, BMI, and disease duration $(\rho=0.234, p=0.017)$. No significant correlations were found within the differently treated MS groups (data not shown). There was no correlation between the lymphocyte count and the anti-RBD antibody titer $(\rho=0.132, p=0.211)$ (Table 3 ), whereas quantitative IFN- $\gamma-\mathrm{T}$-cell-specific response correlated with lymphocyte count in the whole MS group $(\rho=0.569, p<0.001)$, but not in the single DMTstreated subgroup (Figure 3B and Table 3).

\section{Correlation Between Anti-RBD Antibody Titer and Neutralization Activity}

We evaluated the neutralization activity in the sera of 69 HCWs (88.5\%). All the enrolled HCWs showed detectable neutralizing antibodies, whose titer significantly correlated with anti-RBD titers $(\rho=0.754, p<0.001)$ (Figure 4A). Among patients with MS, the neutralization test was performed only in 24 (68.6\%) patients treated with fingolimod due to the low antibody titers, to characterize the neutralizing capacity of the specific antibodies elicited by vaccination. Only 4/24 (16.6\%) patients showed a neutralizing activity, although at low titer (Figure 4B), with a significant correlation between the neutralizing antibody and anti-RBD antibody titers $(\rho=0.591, p=0.0024)$.

This study provides Class III data that SARS-CoV-2 mRNA vaccination induces both humoral and cell-mediated specific immune responses against viral spike proteins in a majority of patients with MS.

\section{Discussion}

This study combines analysis of humoral- and cell-mediated immunity responses to SARSCoV-2 vaccination in people with MS treated with different DMTs.

Mass vaccination against SARS-CoV-2 is crucial for control of the pandemic that is ongoing in large populations all over the world. A coordinated humoral- and cell-mediated response induced by specific vaccination is the only tool available for more effective prevention of SARS-CoV-2 infection, symptom onset, and severe disease outcome. ${ }^{13,14}$ In particular, the humoral response blocks viral replication itself, whereas the viral-specific T-cell response kills viralinfected cells. ${ }^{30}$

Recently, Achiron et al. ${ }^{17}$ demonstrated, in a cohort of 125 patients with MS, the development of COVID-19 humoral response to the mRNA-based vaccine BNT162b2 in all untreated 
Table 3 Factors Associated With Antibody and T-Cell-Specific Responses in Patients With Multiple Sclerosis

\begin{tabular}{|c|c|c|c|c|c|}
\hline & All $(n=108)$ & Ocrelizumab $(n=25)$ & Fingolimod $(n=35)$ & Cladribine $(n=20)$ & IFN- $\beta(n=28)$ \\
\hline \multicolumn{6}{|l|}{ Age } \\
\hline Anti-RBD Abs, BAU/mL & $\rho=-0.145 ; p=0.134$ & $\rho=-0.118 ; p=0.574$ & $\rho=-0.059 ; p=0.734$ & $\rho=-0.471 ; p=0.036$ & $\rho=-0.002 ; p=0.990$ \\
\hline Anti-spike IFN-y, pg/mL & $\rho=-0.103 ; p=0.287$ & $\rho=0.025 ; p=0.906$ & $-0.190 ; p=0.267$ & $\rho=-0.168 ; p=0.478$ & $\rho=-0.196 ; p=0.327$ \\
\hline \multicolumn{6}{|l|}{ BMI } \\
\hline Anti-RBD Abs, BAU/mL & $\rho=0.060 ; p=0.535$ & $\rho=0.361 ; p=0.076$ & $\rho=-0.174 ; p=0.310$ & $\rho=0.026 ; p=0.915$ & $\rho=-0.249 ; p=0.211$ \\
\hline Anti-spike IFN-y, pg/mL & $\rho=-0.162 ; p=0.095$ & $\rho=-0.073 ; p=0.0727$ & $\rho=-0.044 ; p=0.798$ & $\rho=-0.217 ; p=0.359$ & $\rho=-0.031 ; p=0.880$ \\
\hline \multicolumn{6}{|l|}{ Disease duration } \\
\hline Anti-RBD Abs, BAU/mL & $\rho=0.097 ; p=0.319$ & $\rho=0.159 ; p=0.447$ & $\rho=0.083 ; p=0.631$ & $\rho=-0.535 ; p=0.015$ & $\rho=0.192 ; p=0.337$ \\
\hline Anti-spike IFN-y, pg/mL & $\rho=-0.066 ; p=0.495$ & $\rho=0.229 ; p=0.271$ & $\rho=-0.170 ; p=0.323$ & $\rho=-0.179 ; p=0.450$ & $\rho=-0.120 ; p=0.550$ \\
\hline \multicolumn{6}{|l|}{ Lymphocyte count } \\
\hline Anti-RBD Abs, BAU/mL & $\rho=0.132 ; p=0.211$ & $\rho=-0.261 ; p=0.466$ & $\rho=-0.012 ; p=0.944$ & $\rho=0.185 ; p=0.435$ & - \\
\hline Anti-spike IFN-y, pg/mL & $\rho=0.569^{\mathrm{a}} ; p<0.001^{\mathrm{a}}$ & $\rho=-0.316 ; p=0.374$ & $\rho=0.099 ; p=0.564$ & $\rho=-0.095 ; p=0.691$ & - \\
\hline
\end{tabular}

Treatment duration

\begin{tabular}{llllll}
\hline Anti-RBD Abs, BAU $/ \mathrm{mL}$ & $\rho=0.193 ; p=0.045$ & $\rho=-0.529^{\mathrm{a}} ; \boldsymbol{p}=0.007^{\mathrm{a}}$ & $\rho=-0.220 ; p=0.198$ & $\rho=0.289 ; p=0.217$ & $\rho=0.230 ; p=0.249$ \\
\hline Anti-spike IFN-y, pg/mL & $\rho=-0.160 ; p=0.099$ & $\rho=0.005 ; p=0.983$ & $\rho=-0.313 ; p=0.063$ & $\rho=-0.384 ; p=0.095$ & $\rho=0.189 ; p=0.344$
\end{tabular}

Abbreviations: $\mathrm{Abs}=$ antibodies; $\mathrm{BAU}=$ binding arbitrary unit; $\mathrm{BMI}=$ body mass index; IFN = interferon; RBD = receptor-binding domain.

${ }^{\text {a }}$ Significant after multiplicity correction by the Bonferroni method $(\alpha / 4=0.0125)$.

patients with MS and in all patients treated with cladribine. In the same study, only $22.7 \%$ of patients treated with ocrelizumab and $3.8 \%$ of patients treated with fingolimod developed SARS-CoV2 antibodies. These results were confirmed in a very small French cohort, ${ }^{31}$ and, only partially, in an Italian series of 32 patients with MS showing the humoral response in 32.5\% (6/ 16) patients treated with ocrelizumab, but also in $62.5 \%(10 / 16)$ of patients treated with fingolimod. ${ }^{20}$

In this study, we demonstrate a normal qualitative and quantitative humoral response to COVID-19 vaccination in patients treated with IFN- $\beta$. We confirm that $100 \%$ of patients treated with cladribine developed a humoral response to mRNA-based vaccines, although the antibody titer was slightly lower than HCWs. We found a detectable humoral response in $85.7 \%$ of the patients treated with fingolimod and in $40 \%$ of those treated with ocrelizumab, both with an anti-RBD-antibody titer significantly reduced compared to HCWs. These findings are in agreement with previous results on vaccines other than COVID-19, showing a humoral response similar to healthy people in IFN- $\beta$-treated patients, ${ }^{32}$ and a reduced antibody titer in patients treated with ocrelizumab $^{33}$ and fingolimod. ${ }^{34}$ The higher proportion of positive specific antispike serologic response in patients with MS treated with fingolimod and ocrelizumab compared to that reported by Achiron et al. ${ }^{17}$ might be due to the more accurate serologic tests used here to detect the specific response.
Few data are available regarding the $\mathrm{T}$-cell-specific response induced by COVID-19 vaccination in treated or untreated patients with MS. Recently, Apostolidis et al. ${ }^{35}$ showed that anti-CD20 agents significantly reduced spike- and RBDspecific antibody and memory B-cell responses in most patients with MS. This effect was dependent on the time from the last anti-CD20 treatment and from the extent of the B-cell reconstitution. ${ }^{35}$ Compared to this work, here, we report evidence of quantitative and qualitative SARS-CoV-2-spikespecific T-cell response in a larger cohort of patients with MS ( $\mathrm{n}=108$ vs $\mathrm{n}=20)$ treated not only with anti-CD20 drugs, but also with other different DMTs. In the current study, Tcell-specific response was observed in $92 \%$ of patients treated with ocrelizumab, $89.3 \%$ of the patients treated with IFN- $\beta$, and $70 \%$ of the patients treated with cladribine, but only in $14 \%$ of the fingolimod-treated patients. IFN- $\gamma-\mathrm{T}$-cellspecific response was lower in all treated patients with MS compared to HCWs, in agreement with Apostolidis et al. ${ }^{35}$ describing the results from only 1 cohort under anti-CD20 treatment. Moreover, we analyzed the $\mathrm{T}$-cell response by an easy-to-perform assay on whole blood, quantifying the IFN- $\gamma$ produced by $T$ cells after specific stimulation. ${ }^{24,36}$ Accordingly, these results correlated with the number of lymphocytes.

Ocrelizumab is an anti-CD20 monoclonal antibody that depletes B lymphocytes and interferes with the process of antibody production. ${ }^{37}$ This mechanism leads to a reduced 
A. CD4
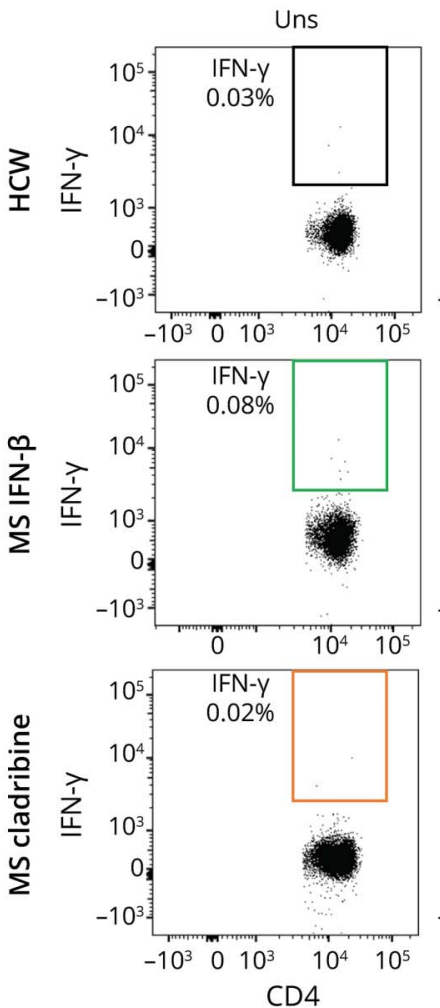

B. $\mathrm{CD} 8$
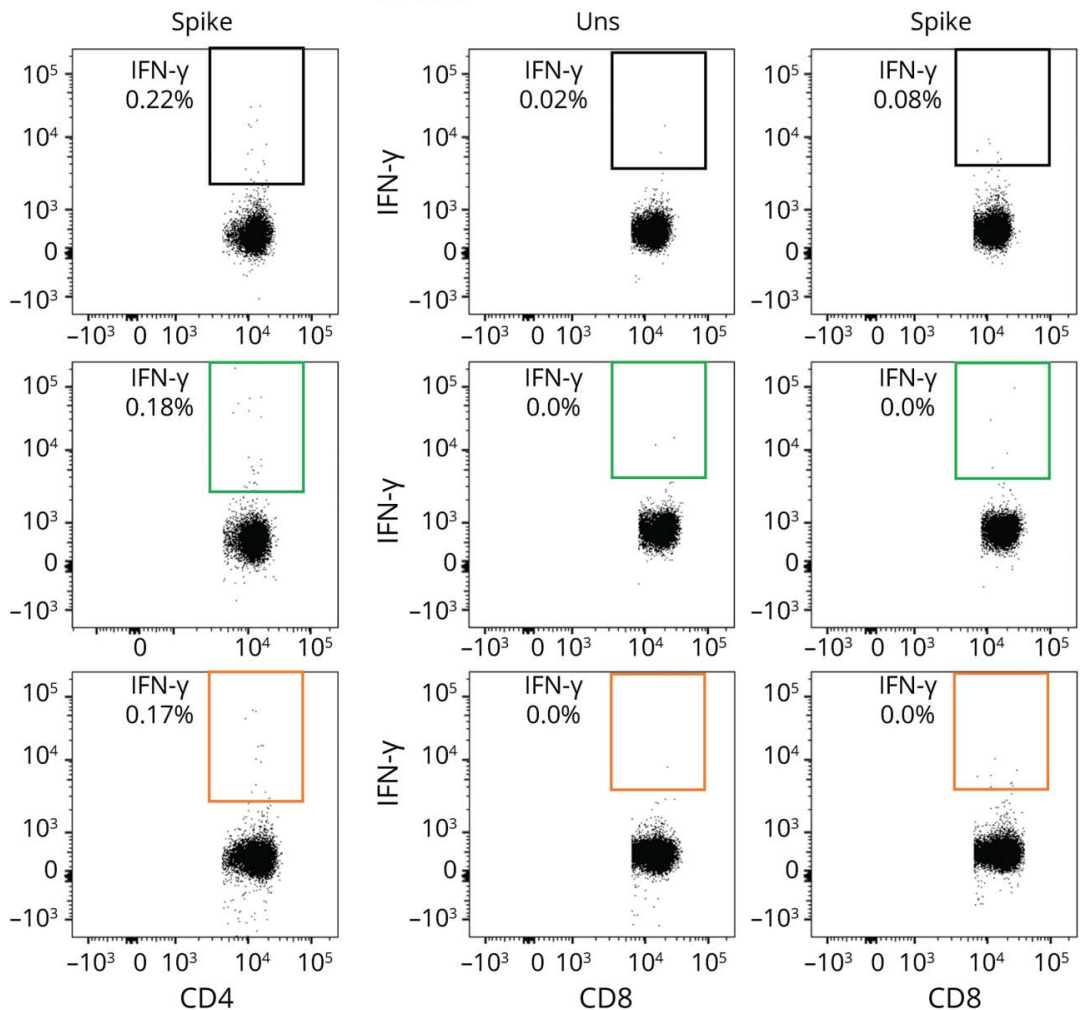

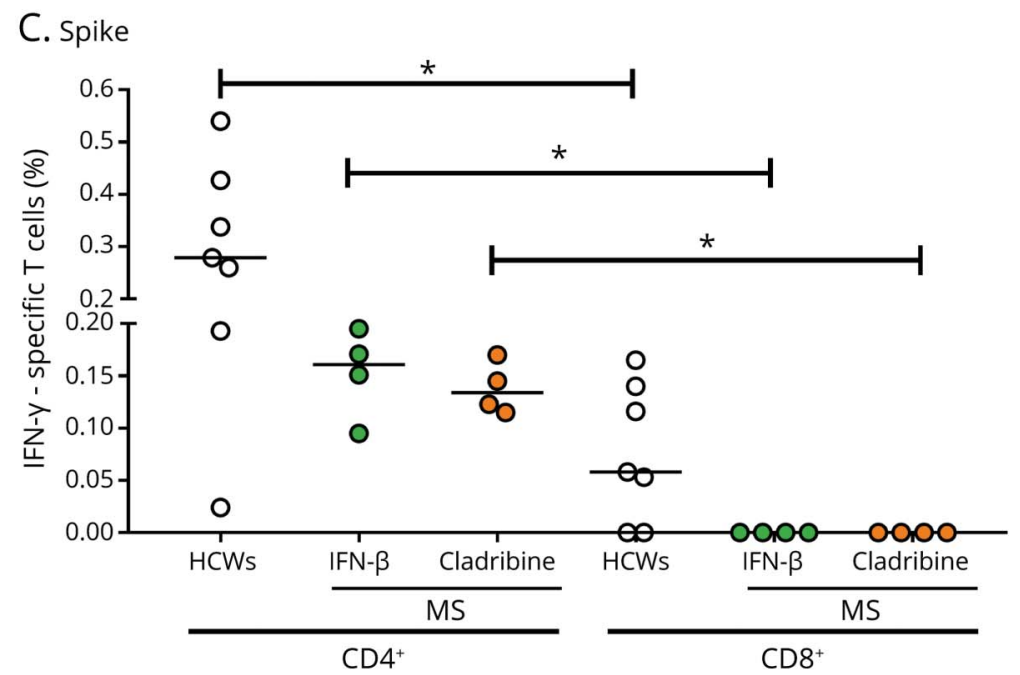

Health care workers (HCWs) $(n=7)$ and patients with multiple sclerosis (MS) (interferon [IFN]- $\beta$-treated $n=4$; cladribine-treated $n=4$ ) were stimulated for 24 hours with spike peptide pool and the frequency of IFN-y-specific T cells was evaluated by flow cytometry. Plots show the frequency of IFN-y-specific T cells in a representative HCW, patient with MS treated with IFN- $\beta$, and patient with MS under cladribine within the CD4 ${ }^{+}$subset $(A)$ and $C D 8^{+}$T-subset $(B)$. (C) Frequency of the $\mathrm{CD}^{+}$and $\mathrm{CD} 8^{+} \mathrm{T}$-cell responses (after subtraction of the unstimulated condition value) is shown in HCWs and patients with MS. Each dot represents a different HCW or patient with MS and black lines represent medians. Statistical analysis was performed using the Mann-Whitney test and $p$ value was considered significant if $\leq 0.05$.

humoral response to vaccination, a higher risk of severe COVID-19, ${ }^{2-4,19}$ and the possibility of persistent SARS-CoV-2 infection in ocrelizumab-treated patients despite the induction of a SARS-CoV-2-specific T-cell response. ${ }^{38}$ It is well known that serum $\operatorname{IgG}$ and IgM levels decrease with ocrelizumab treatment duration ${ }^{39}$; this is confirmed by our results showing a relationship between treatment duration and the entity of the humoral response to SARS-CoV-2 vaccine. We show that ocrelizumab-treated patients mount a spike-specific T-cell response comparable to that developed in patients treated with IFN- $\beta$ or cladribine. Whether the presence of a $\mathrm{T}$-cell response, associated to an impaired humoral immunity, might be sufficient to control SARSCoV-2 infection is a matter of debate ${ }^{38}$ and outside the 


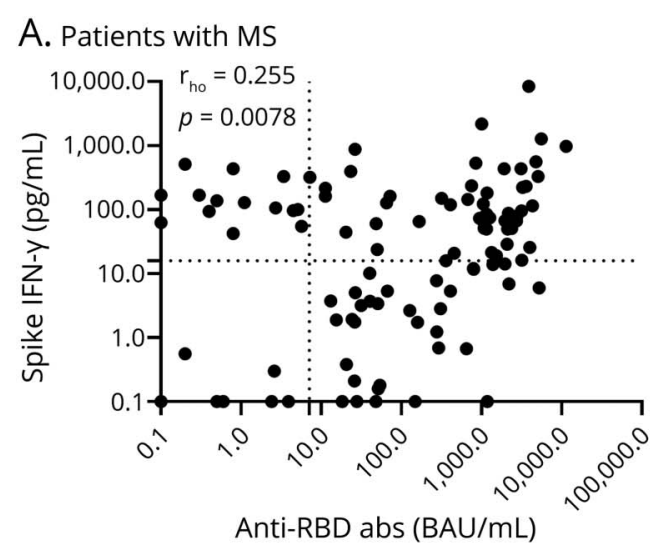

B. Patients with MS

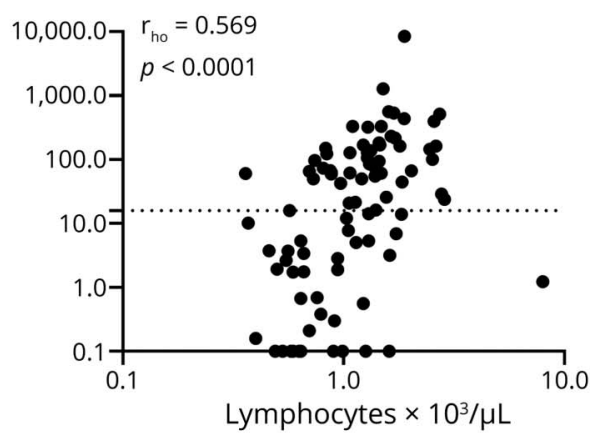

Anti-RBD abs (BAU/mL)
(A) Evaluation of correlation between interferon (IFN)-y levels in response to spike and anti-receptor-binding domain (RBD) antibodies (Abs) in 108 patients with multiple sclerosis (MS). Anti-RBD immunoglobulin $G$ was expressed as binding arbitrary units $(\mathrm{BAU}) / \mathrm{mL}$ and values $\geq 7.1$ were considered positive. A slight significant correlation was found in patients with MS ( $\rho=0.255, p=0.0078)$. (B) Evaluation of correlation between IFN-y levels in response to spike and lymphocyte number in a subgroup of patients with MS $(n=87)$. IFN-y levels correlate with lymphocyte number in patients with MS $(\rho=0.569, p<$ 0.0001 ). Dashed lines identify the cutoff of each test (spike $16 \mathrm{pg} / \mathrm{mL}$ and anti-RBD 7.1 BAU/mL). Each black dot represents 1 sample. Correlations between assays were assessed by nonparametric Spearman's rank tests. A 2-sided $p$ value $<0.05$ was considered statistically significant. purpose of this study. However, preservation of the T-cell response might explain why ongoing treatment with ocrelizumab is not always associated with an increased severity of SARS-CoV-2 infection, ${ }^{40}$ and why in a small cohort of antiCD20-treated patients a low frequency of vaccine failure has been reported. ${ }^{31}$ Lastly, the long-term potential beneficial effect of the SARS-CoV-2-specific T-cell response might contribute to reduce COVID-19 disease severity.

Fingolimod is a sphingosine 1-phospate modulator that prevents $\mathrm{T}$ cell egress from lymph nodes, reducing the number of circulating lymphocytes. This mechanism supports our results showing both reduced T-cell-specific and humoral responses in fingolimod-treated patients. We demonstrate also that only a minority of patients treated with fingolimod have an antiviral neutralizing capacity.

In vitro T-cell response to SARS-CoV-2 spike glycoprotein is mediated by both $\mathrm{CD}^{+}$and $\mathrm{CD}^{+} \mathrm{T}$ cells ${ }^{11,24}$ and was confirmed in our vaccinated $\mathrm{HCW}$ s cohort. ${ }^{27} \mathrm{CD} 8^{+} \mathrm{T}$-cell response was not found in patients treated with cladribine or IFN- $\beta$. It is known that these treatments may have an effect on both $\mathrm{CD} 4^{+}$ and $\mathrm{CD}^{+}$T-cell populations ${ }^{41,42}$ and that spike-specific response by $\mathrm{CD}^{+} \mathrm{T}$ cells is only one-tenth of the $\mathrm{CD}^{+} \mathrm{T}$-cell response $^{24,36}$ and therefore difficult to detect if present. These results need to be confirmed in larger cohorts of patients.

This study has some limitations. First, the small size of the cohort restricts the power of the study, especially for the comparison of the effects of vaccination between different DMTs. Nevertheless, the enrolled participants are representative of patients with MS and are well characterized, both clinically and immunologically. Second, the evaluation of immune responses was done at a single time point postvaccination and the methodology used to detect the T-cell response was based on the measurement of a single cytokine (IFN- $\gamma$ ), differently from published studies evaluating additional T-helper 1 cytokines. ${ }^{12,23}$ However, as we have shown, the IFN- $\gamma$ T-cell response correlates with RBD antibody titers, $^{12}$ therefore IFN- $\gamma$ may be considered as a robust parameter to measure the $\mathrm{T}$-cell-specific response induced after vaccination.

One of the main strengths of this study, compared to prior works, ${ }^{17,18,20}$ is the evaluation of the humoral immune response using both specific anti-RBD IgG and SARS-CoV-2 neutralization tests, in addition to characterization of the $\mathrm{T}$-cell response in terms of both $\mathrm{CD}^{+}$or $\mathrm{CD}^{+} \mathrm{T}$-cell involvement. The assays used in this study to detect SARS-CoV2 -specific response are easy and highly reproducible, ${ }^{24,36}$ and therefore, compatible with the routine monitoring of vaccinated people. Indeed, the $\mathrm{T}$-cell response was detected using a whole blood assay, whose platform is similar to current tests measuring the T-cell-specific responses against Mycobacterium tuberculosis. ${ }^{43}$

This is the first study demonstrating the development of a Tcell-specific response to SARS-CoV-2 in the majority of DMT-treated patients with the lowest rate in patients treated with fingolimod. Together with the observation concerning the humoral response, these data carry relevant implications for managing vaccinations in people with MS, suggesting to promote vaccination in all treated patients with MS. Future studies are needed to evaluate the longevity of the humoral and $\mathrm{T}$-cell responses following COVID-19 vaccination in patients with MS and the effect of different time window vaccination on immunity development in patients treated with ocrelizumab. These data will be key for defining the best vaccination strategy to balance the risk of MS disease progression and protection against SARS-CoV-2 infection. 

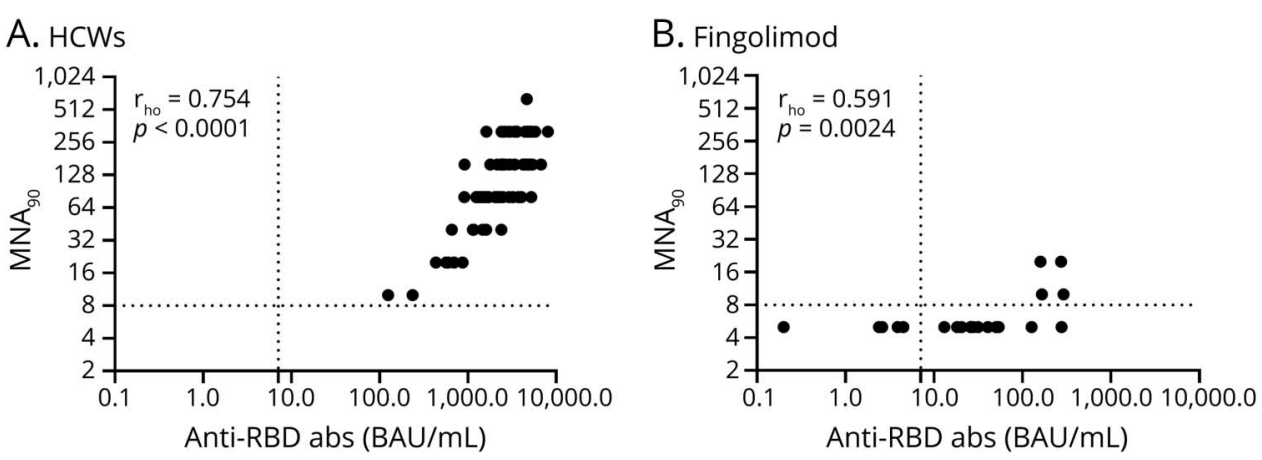

\begin{abstract}
The correlation between antireceptor-binding domain (RBD) immunoglobulin G (IgG) levels and neutralizing antibodies (Abs) was evaluated in a subgroup of the (A) enrolled health care workers (HCWs) $(n=69)$ and (B) patients with multiple sclerosis (MS) under fingolimod therapy ( $n=24)$. Anti-RBD IgG was expressed as binding arbitrary units $(B A U) / m L$ and values $\geq 7.1$ were considered positive; neutralizing antibodies were expressed as the reciprocal of dilution and values $\geq 10$ were considered positive. A strong significant correlation was found in HCWs $(\rho=0.754, p<0.0001)$, whereas a moderate correlation was found in patients with MS $(\rho=0.591, p=$ 0.0024). Dashed lines identify the cutoff of each test (anti-RBD 7.1 BAU/ $\mathrm{mL}$ and $\mathrm{MNA}_{90}$ 8). Each black dot represents 1 sample. Correlations between assays were assessed by nonparametric Spearman's rank tests. A 2-sided $p$ value $<0.05$ was considered statistically significant.
\end{abstract}

\section{Acknowledgment}

The authors thank the nurses of the MS Centre of the San Camillo Forlanini Hospital, the study patients, and the collaborators of the National Institute for Infectious Diseases (INMI) COVID-19 Vaccine Study Group: Daniele Lapa, Massimo Francalancia, Aurora Bettini, Giulia Gramigna, Federica Forbici, Paola Gallì, Alessandra Marani, Adriano Possi, Andrea Capri, Annapaola Santoro, Nicoletta Orchi, Ornella Butera, Linda Petrone, and Elisa Petruccioli.

\section{Study Funding}

Supported by INMI "Lazzaro Spallanzani” Ricerca Finalizzata COVID-2020-12371675 and Ricerca Corrente on emerging infections, both funded by Italian Ministry of Health, and by funding for COVID-19 research from Esselunga SpA, Camera di Commercio, Industria e Artigianato di Roma, Società Numero Blu Servizi SpA, Fineco Bank SpA, Associazione Magistrati della Corte dei Conti, and Società Mocerino Frutta Secca srl.

\section{Disclosures}

C. Tortorella received honoraria for speaking, travel grants, and advisory board from Biogen, Merck-Serono, Bayer-Schering, Teva, Sanofi, Roche, Mylan, Almirall, and Novartis. A. Aiello reports no disclosures relevant to the manuscript. C. Gasperini received fees as speaker or advisory board from Merck, Bayer, Biogen, Novartis, Teva, Sanofi, Roche Almirall, and Mylan. C. Agrati, C. Castilletti, S. Meschi, G. Matusali, F. Colavita, C. Farroni, G. Cuzzi, E. Cimini, E. Tartaglia, and V. Vanini report no disclosures relevant to the manuscript. S. Ruggieri has received honoraria from Biogen, Merck Serono, Novartis, and Teva for consulting services, speaking, and/ or travel support. L. Prosperini received consulting fees and/or speaker honoraria from Biogen, Celgene, Genzyme, MerckSerono, Novartis, and Teva; travel grants from Biogen, Genzyme, Novartis, and Teva; and research grants from the Italian MS

Society (Associazione Italiana Sclerosi Multipla) and Genzyme. S. Haggiag received travel funding and/or speaker honoraria from Biogen, Roche, Genzyme, Novartis, and CSL Behring. S. Galgani received honoraria for speaking and travel grants from Biogen, Sanofi-Aventis, Merck Serono, Bayer-Schering, Teva, Genzyme, Almirall, and Novartis. M.E. Quartuccio, A. Salmi, F. Repele, A.M.G. Altera, F. Cristofanelli, A. D’Abramo, N. Bevilacqua, A. Corpolongo, V. Puro, F. Vaia, M.R. Capobianchi, and G. Ippolito report no disclosures relevant to the manuscript. E. Nicastri is a member of the advisory board for Gilead, Lilly, and Roche and received fees for educational training from Gilead, Lilly, and Roche. D. Goletti is a member of the advisory board for bioMérieux and Eli-Lilly and received fees for educational training or consultancy from Biogen, Celgene, DiaSorin, Janssen, Qiagen, and Quidel. Go to Neurology.org/ $\mathrm{N}$ for full disclosures.

\section{Publication History}

Received by Neurology July 7, 2021. Accepted in final form November 4, 2021.

Appendix Authors

\begin{tabular}{lll}
\hline Name & Location & Contribution \\
\hline $\begin{array}{l}\text { Carla } \\
\text { Mortorella, }\end{array}$ & $\begin{array}{l}\text { Department of } \\
\text { Neurosciences, San Camillo- } \\
\text { Forlanini Hospital, Rome, } \\
\text { Italy }\end{array}$ & $\begin{array}{l}\text { Drafting/revision of the } \\
\text { manuscript for content, } \\
\text { including medical writing } \\
\text { for content; major role in } \\
\text { the acquisition of data; } \\
\text { analysis or interpretation } \\
\text { of data }\end{array}$ \\
\hline $\begin{array}{ll}\text { Alessandra } \\
\text { Aiello, PhD }\end{array}$ & $\begin{array}{l}\text { Translational Research Unit, } \\
\text { National Institute for } \\
\text { Infectious Diseases Lazzaro }\end{array}$ & $\begin{array}{l}\text { Drafting/revision of the } \\
\text { manuscript for content, } \\
\text { including medical writing for } \\
\text { content; major role in the } \\
\text { acquisition of data; analysis } \\
\text { Spallanzani-IRCCS, Rome, interpretation of data } \\
\text { Italy }\end{array}$ \\
\end{tabular}


Appendix (continued)

\begin{tabular}{|c|c|c|}
\hline Name & Location & Contribution \\
\hline $\begin{array}{l}\text { Claudio } \\
\text { Gasperini, } \\
\text { MD, PhD }\end{array}$ & $\begin{array}{l}\text { Department of } \\
\text { Neurosciences, San Camillo- } \\
\text { Forlanini Hospital, Rome, } \\
\text { Italy }\end{array}$ & $\begin{array}{l}\text { Drafting/revision of the } \\
\text { manuscript for content, } \\
\text { including medical writing for } \\
\text { content; major role in the } \\
\text { acquisition of data }\end{array}$ \\
\hline $\begin{array}{l}\text { Chiara } \\
\text { Agrati, PhD }\end{array}$ & $\begin{array}{l}\text { Laboratory of Cellular } \\
\text { Immunology, National } \\
\text { Institute for Infectious } \\
\text { Diseases Lazzaro } \\
\text { Spallanzani-IRCCS, Rome, } \\
\text { Italy }\end{array}$ & $\begin{array}{l}\text { Drafting/revision of the } \\
\text { manuscript for content, } \\
\text { including medical writing for } \\
\text { content; major role in the } \\
\text { acquisition of data; study } \\
\text { concept or design }\end{array}$ \\
\hline $\begin{array}{l}\text { Concetta } \\
\text { Castilletti, } \\
\text { PhD }\end{array}$ & $\begin{array}{l}\text { Laboratory of Virology, } \\
\text { National Institute for } \\
\text { Infectious Diseases Lazzaro } \\
\text { Spallanzani-IRCCS, Rome, } \\
\text { Italy }\end{array}$ & $\begin{array}{l}\text { Drafting/revision of the } \\
\text { manuscript for content, } \\
\text { including medical writing for } \\
\text { content; major role in the } \\
\text { acquisition of data; study } \\
\text { concept or design }\end{array}$ \\
\hline $\begin{array}{l}\text { Serena } \\
\text { Ruggieri, MD, } \\
\text { PhD }\end{array}$ & $\begin{array}{l}\text { Department of Human } \\
\text { Neurosciences, Sapienza } \\
\text { University of Rome; } \\
\text { Neuroimmunology Unit, } \\
\text { IRCSS Fondazione Santa } \\
\text { Lucia, Rome, Italy }\end{array}$ & $\begin{array}{l}\text { Drafting/revision of the } \\
\text { manuscript for content, } \\
\text { including medical writing for } \\
\text { content; major role in the } \\
\text { acquisition of data }\end{array}$ \\
\hline $\begin{array}{l}\text { Silvia Meschi, } \\
\text { PhD }\end{array}$ & $\begin{array}{l}\text { Laboratory of Virology, } \\
\text { National Institute for } \\
\text { Infectious Diseases Lazzaro } \\
\text { Spallanzani-IRCCS, Rome, Italy }\end{array}$ & $\begin{array}{l}\text { Major role in the acquisition } \\
\text { of data }\end{array}$ \\
\hline $\begin{array}{l}\text { Giulia } \\
\text { Matusali, } \\
\text { PhD }\end{array}$ & $\begin{array}{l}\text { Laboratory of Virology, } \\
\text { National Institute for } \\
\text { Infectious Diseases Lazzaro } \\
\text { Spallanzani-IRCCS, Rome, } \\
\text { Italy }\end{array}$ & $\begin{array}{l}\text { Major role in the acquisition } \\
\text { of data }\end{array}$ \\
\hline
\end{tabular}

\begin{tabular}{|c|c|c|}
\hline $\begin{array}{l}\text { Francesca } \\
\text { Colavita, PhD }\end{array}$ & $\begin{array}{l}\text { Laboratory of Virology, } \\
\text { National Institute for } \\
\text { Infectious Diseases Lazzaro } \\
\text { Spallanzani-IRCCS, Rome, Italy }\end{array}$ & $\begin{array}{l}\text { Major role in the acquisition } \\
\text { of data }\end{array}$ \\
\hline $\begin{array}{l}\text { Chiara } \\
\text { Farroni, PhD }\end{array}$ & $\begin{array}{l}\text { Translational Research Unit, } \\
\text { National Institute for } \\
\text { Infectious Diseases Lazzaro } \\
\text { Spallanzani-IRCCS, Rome, Italy }\end{array}$ & $\begin{array}{l}\text { Major role in the acquisition } \\
\text { of data; analysis or } \\
\text { interpretation of data }\end{array}$ \\
\hline $\begin{array}{l}\text { Gilda Cuzzi, } \\
\text { MSc }\end{array}$ & $\begin{array}{l}\text { Translational Research Unit, } \\
\text { National Institute for } \\
\text { Infectious Diseases Lazzaro } \\
\text { Spallanzani-IRCCS, Rome, Italy }\end{array}$ & $\begin{array}{l}\text { Major role in the acquisition } \\
\text { of data }\end{array}$ \\
\hline $\begin{array}{l}\text { Eleonora } \\
\text { Cimini, PhD }\end{array}$ & $\begin{array}{l}\text { Laboratory of Cellular } \\
\text { Immunology, National } \\
\text { Institute for Infectious } \\
\text { Diseases Lazzaro Spallanzani- } \\
\text { IRCCS, Rome, Italy }\end{array}$ & $\begin{array}{l}\text { Major role in the acquisition } \\
\text { of data }\end{array}$ \\
\hline $\begin{array}{l}\text { Eleonora } \\
\text { Tartaglia, } \\
\text { MSc }\end{array}$ & $\begin{array}{l}\text { Laboratory of Cellular } \\
\text { Immunology, National } \\
\text { Institute for Infectious } \\
\text { Diseases Lazzaro } \\
\text { Spallanzani-IRCCS, Rome, } \\
\text { Italy }\end{array}$ & $\begin{array}{l}\text { Major role in the acquisition } \\
\text { of data }\end{array}$ \\
\hline $\begin{array}{l}\text { Valentina } \\
\text { Vanini, MLT }\end{array}$ & $\begin{array}{l}\text { Translational Research Unit, } \\
\text { National Institute for } \\
\text { Infectious Diseases Lazzaro } \\
\text { Spallanzani-IRCCS; UOS } \\
\text { Professioni Sanitarie } \\
\text { Tecniche, National Institute } \\
\text { for Infectious Diseases } \\
\text { Lazzaro Spallanzani-IRCCS, } \\
\text { Rome, Italy }\end{array}$ & $\begin{array}{l}\text { Major role in the acquisition } \\
\text { of data }\end{array}$ \\
\hline
\end{tabular}

Appendix (continued)

\begin{tabular}{|c|c|c|}
\hline Name & Location & Contribution \\
\hline $\begin{array}{l}\text { Luca } \\
\text { Prosperini, } \\
\text { MD, PhD }\end{array}$ & $\begin{array}{l}\text { Department of } \\
\text { Neurosciences, San Camillo- } \\
\text { Forlanini Hospital, Rome, } \\
\text { Italy }\end{array}$ & $\begin{array}{l}\text { Drafting/revision of the } \\
\text { manuscript for content, } \\
\text { including medical writing for } \\
\text { content; major role in the } \\
\text { acquisition of data; analysis } \\
\text { or interpretation of data }\end{array}$ \\
\hline
\end{tabular}

\begin{tabular}{lll}
\hline Shalom & Department of & Drafting/revision of the \\
Haggiag, MD & $\begin{array}{l}\text { Neurosciences, San Camillo- } \\
\text { Forlanini Hospital, Rome, }\end{array}$ & $\begin{array}{l}\text { manuscript for content, } \\
\text { including medical writing for } \\
\text { content }\end{array}$
\end{tabular}

\begin{tabular}{|c|c|c|}
\hline $\begin{array}{l}\text { Simona } \\
\text { Galgani, MD }\end{array}$ & $\begin{array}{l}\text { Department of } \\
\text { Neurosciences, San Camillo- } \\
\text { Forlanini Hospital, Rome, } \\
\text { Italy }\end{array}$ & $\begin{array}{l}\text { Drafting/revision of the } \\
\text { manuscript for content, } \\
\text { including medical writing for } \\
\text { content; major role in the } \\
\text { acquisition of data }\end{array}$ \\
\hline
\end{tabular}

\begin{tabular}{|c|c|c|}
\hline $\begin{array}{l}\text { Maria } \\
\text { Esmeralda } \\
\text { Quartuccio, } \\
\text { MD }\end{array}$ & $\begin{array}{l}\text { Department of } \\
\text { Neurosciences, San Camillo- } \\
\text { Forlanini Hospital, Rome, } \\
\text { Italy }\end{array}$ & $\begin{array}{l}\text { Drafting/revision of the } \\
\text { manuscript for content, } \\
\text { including medical writing for } \\
\text { content; major role in the } \\
\text { acquisition of data }\end{array}$ \\
\hline
\end{tabular}

Andrea Translational Research Unit, Major role in the acquisition

Salmi, MLT National Institute for of data Infectious Diseases Lazzaro Spallanzani-IRCCS, Rome, Italy

\begin{tabular}{lll}
\hline $\begin{array}{l}\text { Federica } \\
\text { Repele, MSc }\end{array}$ & $\begin{array}{l}\text { Translational Research Unit, } \\
\text { National Institute for } \\
\text { Infectious Diseases Lazzaro } \\
\text { Spallanzani-IRCCS, Rome, Italy }\end{array}$ & $\begin{array}{l}\text { Major role in the acquisition } \\
\text { of data }\end{array}$ \\
&
\end{tabular}

Anna Maria Translational Research Unit, Major role in the acquisition Gerarda National Institute for of data

Altera, MLT Infectious Diseases Lazzaro Spallanzani-IRCCS, Rome, Italy

\begin{tabular}{lll}
\hline Flavia & Laboratory of Cellular & Major role in the acquisition \\
Cristofanelli, & Immunology, National & of data \\
MSc & Institute for Infectious & \\
& Diseases Lazzaro Spallanzani- & \\
& IRCCS, Rome, Italy &
\end{tabular}

\begin{tabular}{lll}
\hline $\begin{array}{l}\text { Alessandra } \\
\text { D'Abramo, } \\
\text { MD }\end{array}$ & $\begin{array}{l}\text { Clinical Division of Infectious } \\
\text { Diseases, National Institute } \\
\text { for Infectious Diseases } \\
\text { Lazzaro Spallanzani-IRCCS, } \\
\text { Rome, Italy }\end{array}$ & $\begin{array}{l}\text { Drafting/revision of the } \\
\text { manuscript for content, } \\
\text { including medical writing for } \\
\text { content }\end{array}$ \\
\hline $\begin{array}{l}\text { Nazario } \\
\text { Bevilacqua, } \\
\text { MD }\end{array}$ & $\begin{array}{l}\text { Clinical Division of Infectious } \\
\text { Diseases, National Institute } \\
\text { for Infectious Diseases } \\
\text { Lazzaro Spallanzani-IRCCS, }\end{array}$ & $\begin{array}{l}\text { Drafting/revision of the } \\
\text { manuscript for content, } \\
\text { including medical writing for } \\
\text { content }\end{array}$ \\
& Rome, Italy &
\end{tabular}

Angela Clinical Division of Infectious Drafting/revision of the Corpolongo, Diseases, National Institute manuscript for content, MD for Infectious Diseases including medical writing for Lazzaro Spallanzani-IRCCS, content Rome, Italy

\begin{tabular}{lll}
\hline $\begin{array}{l}\text { Vincenzo } \\
\text { Puro, MD }\end{array}$ & $\begin{array}{l}\text { UOC Emerging Infections and } \\
\text { CRAIDS, National Institute for } \\
\text { Infectious Diseases Lazzaro } \\
\text { Spallanzani-IRCCS, Rome, Italy }\end{array}$ & $\begin{array}{l}\text { Drafting/revision of the } \\
\text { manuscript for content, } \\
\text { including medical writing for } \\
\text { content; study concept or } \\
\text { design }\end{array}$ \\
\hline $\begin{array}{l}\text { Francesco } \\
\text { Vaia, MD }\end{array}$ & $\begin{array}{l}\text { Health Direction, National } \\
\text { Institute for Infectious } \\
\text { Diseases Lazzaro } \\
\text { Spallanzani-IRCCS, Rome, } \\
\text { Italy }\end{array}$ & $\begin{array}{l}\text { Drafting/revision of the } \\
\text { manuscript for content, } \\
\text { including medical writing for } \\
\text { content; study concept or } \\
\text { design }\end{array}$ \\
& &
\end{tabular}


Appendix (continued)

\begin{tabular}{|c|c|c|}
\hline Name & Location & Contribution \\
\hline $\begin{array}{l}\text { Maria } \\
\text { Rosaria } \\
\text { Capobianchi, } \\
\text { PhD }\end{array}$ & $\begin{array}{l}\text { Laboratory of Virology, } \\
\text { National Institute for } \\
\text { Infectious Diseases Lazzaro } \\
\text { Spallanzani-IRCCS, Rome, } \\
\text { Italy }\end{array}$ & $\begin{array}{l}\text { Drafting/revision of the } \\
\text { manuscript for content, } \\
\text { including medical writing for } \\
\text { content; study concept or } \\
\text { design }\end{array}$ \\
\hline $\begin{array}{l}\text { Giuseppe } \\
\text { Ippolito, MD }\end{array}$ & $\begin{array}{l}\text { Scientific Direction, National } \\
\text { Institute for Infectious } \\
\text { Diseases Lazzaro } \\
\text { Spallanzani-IRCCS, Rome, } \\
\text { Italy }\end{array}$ & Study concept or design \\
\hline $\begin{array}{l}\text { Emanuele } \\
\text { Nicastri, MD, } \\
\text { PhD }\end{array}$ & $\begin{array}{l}\text { Clinical Division of Infectious } \\
\text { Diseases, National Institute } \\
\text { for Infectious Diseases } \\
\text { Lazzaro Spallanzani-IRCCS, } \\
\text { Rome, Italy }\end{array}$ & $\begin{array}{l}\text { Drafting/revision of the } \\
\text { manuscript for content, } \\
\text { including medical } \\
\text { writing for content; major } \\
\text { role in the acquisition of } \\
\text { data; study concept or } \\
\text { design }\end{array}$ \\
\hline $\begin{array}{l}\text { Delia Goletti, } \\
\text { MD, PhD }\end{array}$ & $\begin{array}{l}\text { Translational Research Unit, } \\
\text { National Institute for } \\
\text { Infectious Diseases Lazzaro } \\
\text { Spallanzani-IRCCS, Rome, } \\
\text { Italy }\end{array}$ & $\begin{array}{l}\text { Drafting/revision of the } \\
\text { manuscript for content, } \\
\text { including medical writing for } \\
\text { content; study concept or } \\
\text { design; analysis or } \\
\text { interpretation of data }\end{array}$ \\
\hline
\end{tabular}

Appendix 2 Coinvestigators

\begin{tabular}{|c|c|c|c|}
\hline Name & Location & Role & Contribution \\
\hline $\begin{array}{l}\text { Daniele Lapa, } \\
\text { MSc }\end{array}$ & $\begin{array}{l}\text { National Institute for } \\
\text { Infectious Diseases } \\
\text { (INMI) }\end{array}$ & $\begin{array}{l}\text { Site } \\
\text { investigator }\end{array}$ & $\begin{array}{l}\text { Experimental } \\
\text { setup }\end{array}$ \\
\hline $\begin{array}{l}\text { Massimo } \\
\text { Francalancia, } \\
\text { MLT }\end{array}$ & $\begin{array}{l}\text { National Institute for } \\
\text { Infectious Diseases } \\
\text { (INMI) }\end{array}$ & $\begin{array}{l}\text { Site } \\
\text { investigator }\end{array}$ & $\begin{array}{l}\text { Experimental } \\
\text { setup }\end{array}$ \\
\hline $\begin{array}{l}\text { Aurora } \\
\text { Bettini, MLT }\end{array}$ & $\begin{array}{l}\text { National Institute for } \\
\text { Infectious Diseases } \\
\text { (INMI) }\end{array}$ & $\begin{array}{l}\text { Site } \\
\text { investigator }\end{array}$ & $\begin{array}{l}\text { Experimental } \\
\text { setup }\end{array}$ \\
\hline $\begin{array}{l}\text { Giulia } \\
\text { Gramigna, } \\
\text { MSc }\end{array}$ & $\begin{array}{l}\text { National Institute for } \\
\text { Infectious Diseases } \\
\text { (INMI) }\end{array}$ & $\begin{array}{l}\text { Site } \\
\text { investigator }\end{array}$ & $\begin{array}{l}\text { Experimental } \\
\text { setup }\end{array}$ \\
\hline $\begin{array}{l}\text { Federica } \\
\text { Forbici, MSc }\end{array}$ & $\begin{array}{l}\text { National Institute for } \\
\text { Infectious Diseases } \\
\text { (INMI) }\end{array}$ & $\begin{array}{l}\text { Site } \\
\text { investigator }\end{array}$ & $\begin{array}{l}\text { Experimental } \\
\text { setup }\end{array}$ \\
\hline $\begin{array}{l}\text { Paola Galli, } \\
\text { MD }\end{array}$ & $\begin{array}{l}\text { National Institute for } \\
\text { Infectious Diseases } \\
\text { (INMI) }\end{array}$ & $\begin{array}{l}\text { Site } \\
\text { investigator }\end{array}$ & $\begin{array}{l}\text { Site of } \\
\text { enrolment of } \\
\text { HCWs setup }\end{array}$ \\
\hline $\begin{array}{l}\text { Alessandra } \\
\text { Marani, MD }\end{array}$ & $\begin{array}{l}\text { National Institute for } \\
\text { Infectious Diseases } \\
\text { (INMI) }\end{array}$ & $\begin{array}{l}\text { Site } \\
\text { investigator }\end{array}$ & $\begin{array}{l}\text { Site of } \\
\text { enrolment of } \\
\text { HCWs setup }\end{array}$ \\
\hline $\begin{array}{l}\text { Adriano } \\
\text { Possi, MSc }\end{array}$ & $\begin{array}{l}\text { National Institute for } \\
\text { Infectious Diseases } \\
\text { (INMI) }\end{array}$ & Administration & $\begin{array}{l}\text { Site of } \\
\text { enrolment of } \\
\text { HCWs setup }\end{array}$ \\
\hline $\begin{array}{l}\text { Andrea Capri, } \\
\text { MD }\end{array}$ & $\begin{array}{l}\text { National Institute for } \\
\text { Infectious Diseases } \\
\text { (INMI) }\end{array}$ & $\begin{array}{l}\text { Site } \\
\text { investigator }\end{array}$ & $\begin{array}{l}\text { Site of } \\
\text { enrolment of } \\
\text { HCWs setup }\end{array}$ \\
\hline $\begin{array}{l}\text { Annapaola } \\
\text { Santoro, MD }\end{array}$ & $\begin{array}{l}\text { National Institute for } \\
\text { Infectious Diseases } \\
\text { (INMI) }\end{array}$ & $\begin{array}{l}\text { Site } \\
\text { investigator }\end{array}$ & $\begin{array}{l}\text { Site of } \\
\text { enrolment of } \\
\text { HCWs setup }\end{array}$ \\
\hline
\end{tabular}

Appendix 2 (continued)

\begin{tabular}{llll}
\hline Name & Location & Role & Contribution \\
\hline $\begin{array}{l}\text { Nicoletta } \\
\text { Orchi, MD }\end{array}$ & $\begin{array}{l}\text { National Institute for } \\
\text { Infectious Diseases } \\
\text { (INMI) }\end{array}$ & $\begin{array}{l}\text { Site } \\
\text { investigator }\end{array}$ & $\begin{array}{l}\text { Site of } \\
\text { enrolment of } \\
\text { HCWs setup }\end{array}$ \\
\hline $\begin{array}{l}\text { Ornella } \\
\text { Butera, MLT }\end{array}$ & $\begin{array}{l}\text { National Institute for } \\
\text { Infectious Diseases } \\
\text { (INMI) }\end{array}$ & $\begin{array}{l}\text { Site } \\
\text { investigator }\end{array}$ & $\begin{array}{l}\text { Experimental } \\
\text { setup }\end{array}$ \\
\hline $\begin{array}{l}\text { Saeid Najafi } \\
\text { Fard, PhD }\end{array}$ & $\begin{array}{l}\text { National Institute for } \\
\text { Infectious Diseases } \\
\text { (INMI) }\end{array}$ & $\begin{array}{l}\text { Site } \\
\text { investigator }\end{array}$ & $\begin{array}{l}\text { Experimental } \\
\text { setup }\end{array}$ \\
\hline $\begin{array}{l}\text { Linda } \\
\text { Petrone, PhD }\end{array}$ & $\begin{array}{l}\text { National Institute for } \\
\text { Infectious Diseases } \\
\text { (INMI) }\end{array}$ & $\begin{array}{l}\text { Site } \\
\text { investigator }\end{array}$ & $\begin{array}{l}\text { Experimental } \\
\text { setup }\end{array}$ \\
\hline $\begin{array}{l}\text { Elisa } \\
\text { Petruccioli, } \\
\text { PhD }\end{array}$ & $\begin{array}{l}\text { National Institute for } \\
\text { Infectious Diseases } \\
\text { (INMI) }\end{array}$ & $\begin{array}{l}\text { Site } \\
\text { investigator }\end{array}$ & $\begin{array}{l}\text { Intellectual } \\
\text { contribution }\end{array}$ \\
\hline
\end{tabular}

\section{References}

1. McGinley MP, Goldschmidt CH, Rae-Grant AD. Diagnosis and treatment of multiple sclerosis: a review. JAMA. 2021;325:765-779.

2. Winkelmann A, Loebermann M, Reisinger EC, Hartung HP, Zettl UK. Diseasemodifying therapies and infectious risks in multiple sclerosis. Nat Rev Neurol. 2016;12: 217-233.

3. Pirttisalo AL, Sipilä JOT, Viitala M, Soilu-Hänninen M. Trends and characteristics of infection-related hospital admissions in multiple sclerosis patients in southwest Finland in 2009-2018. Mult Scler Relat Disord. 2020;44:102328.

4. Luna G, Alping P, Burman J, et al. Infection risks among patients with multiple sclerosis treated with fingolimod, natalizumab, rituximab, and injectable therapies. JAMA Neurol. 2020;77:184-191.

5. Braun J, Loyal L, Frentsch M, et al. SARS-CoV-2-reactive T cells in healthy donors and patients with COVID-19. Nature. 2020;587:270-274.

6. Cantini F, Goletti D, Petrone L, Najafi Fard S, Niccoli L, Foti R. Immune therapy, or antiviral therapy, or both for COVID-19: a systematic review. Drugs. 2020;80: 1929-1946.

7. Goletti D, Cantini F. Baricitinib therapy in covid-19 pneumonia: an unmet need fulfilled. N Engl J Med. 2021;384:867-869.

8. Polack FP, Thomas SJ, Kitchin N, et al. Safety and efficacy of the BNT162b2 mRNA covid-19 vaccine. N Engl J Med. 2020;383:2603-2615.

9. Thompson MG, Burgess JL, Naleway AL, et al. Interim estimates of vaccine effectiveness of BNT162b2 and mRNA-1273 COVID-19 vaccines in preventing SARSCoV-2 infection among health care personnel, first responders, and other essential and frontline workers: eight U.S. locations, December 2020-March 2021. MMWR Morb Mortal Wkly Rep. 2021;70:495-500.

10. Baden LR, El Sahly HM, Essink B, et al. Efficacy and safety of the mRNA-1273 SARSCoV-2 vaccine. N Engl J Med. 2021;384:403-416.

11. Angyal A, Longet S, Moore S, et al. T-cell and antibody responses to first BNT162b2 vaccine dose in previously SARS-CoV-2-infected and infection-naive UK healthcare workers: a multicentre, prospective, observational cohort study. Lancet. Epub 2021 Nov 9.

12. Agrati C, Castilletti C, Goletti D, et al. Coordinate induction of humoral and spike specific T-cell response in a cohort of Italian health care workers receiving BNT162 b2 mRNA vaccine. Microorganisms. 2021;9:1315.

13. Dan JM, Mateus J, Kato Y, et al. Immunological memory to SARS-CoV-2 assessed for up to 8 months after infection. Science. 2021;371:eabf4063.

14. Rydyznski Moderbacher C, Ramirez SI, Dan JM, et al. Antigen-specific adaptive immunity to SARS-CoV-2 in acute COVID-19 and associations with age and disease severity. Cell. 2020;183:996-1012.e19.

15. Ceronie B, Jacobs BM, Baker D, et al. Cladribine treatment of multiple sclerosis is associated with depletion of memory B cells. J Neurol. 2018;265:1199-1209.

16. Jacobs BM, Ammoscato F, Giovannoni G, Baker D, Schmierer K. Cladribine: mechanisms and mysteries in multiple sclerosis. J Neurol Neurosurg Psychiatry. 2018; 89:1266-1271.

17. Achiron A, Mandel M, Dreyer-Alster S, et al. Humoral immune response to COVID19 mRNA vaccine in patients with multiple sclerosis treated with high-efficacy diseasemodifying therapies. Ther Adv Neurol Disord. 2021;14:17562864211012835.

18. Gallo A, Capuano R, Donnarumma G, et al. Preliminary evidence of blunted humoral response to SARS-CoV-2 mRNA vaccine in multiple sclerosis patients treated with ocrelizumab. Neurol Sci. 2021;42:1-4.

19. Sormani MP, De Rossi N, Schiavetti I, et al. Disease-modifying therapies and coronavirus disease 2019 severity in multiple sclerosis. Ann Neurol. 2021;89:780-789. 
20. Guerrieri S, Lazzarin S, Zanetta C, Nozzolillo A, Filippi M, Moiola L. Serological response to SARS-CoV-2 vaccination in multiple sclerosis patients treated with fingolimod or ocrelizumab: an initial real-life experience. J Neurol. 2021;1:1-5.

21. Thompson AJ, Banwell BL, Barkhof F, et al. Diagnosis of multiple sclerosis: 2017 revisions of the McDonald criteria. Lancet Neurol. 2018;17:162-173.

22. Centonze D, Rocca MA, Gasperini C, et al. Disease-modifying therapies and SARSCoV-2 vaccination in multiple sclerosis: an expert consensus. J Neurol. 2021:1-8.

23. Puro V, Castilletti C, Agrati C, et al. Impact of prior influenza and pneumoccocal vaccines on humoral and cellular response to SARS-CoV-2 BNT162b2 vaccination. Vaccines. 2021;9:615.

24. Aiello A, Najafi Fard S, Petruccioli E, et al. Spike is the most recognized antigen in the whole-blood platform in both acute and convalescent COVID-19 patients. Int J Infect Dis. 2021;106:338-347.

25. Murugesan $\mathrm{K}$, Jagannathan $\mathrm{P}$, Pham TD, et al. Interferon-gamma release assay for accurate detection of SARS-CoV-2 T cell response. Clin Infect Dis. 2021;73(9): e3130-e3132.

26. Riou C, Schäfer G, du Bruyn E, et al. Rapid, simplified whole blood-based multiparameter assay to quantify and phenotype SARS-CoV-2 specific T cells. Eur Respir J. 2021;17:2100285.

27. Picchianti Diamanti A, Aiello A, Laganà B, et al. Immunosuppressive therapies differently modulate humoral- and T-cell-specific responses to COVID-19 mRNA vaccine in rheumatoid arthritis patients. Front Immunol. 2021 Sep 14;12:740249.

28. Roederer M. How many events is enough? are you positive?. Cytometry A. 2008; 73 : 384-385.

29. Matusali G, Colavita F, Lapa D, et al. SARS-CoV-2 serum neutralization assay: a traditional tool for a brand-new virus. Viruses. 2021;13:655.

30. Tay MZ, Poh CM, Rénia L, MacAry PA, Ng LFP. The trinity of COVID-19: immunity, inflammation and intervention. Nat Rev Immunol. 2020;20:363-374.

31. Bigaut K, Kremer L, Fleury M, Lanotte L, Collongues N, de Seze J. Impact of diseasemodifying treatments on humoral response after COVID-19 vaccination: a mirror of the response after SARS-CoV-2 infection. Rev Neurol. 2021;177(10):1237-1240.
32. Olberg HK, Eide GE, Cox RJ, et al. Antibody response to seasonal influenza vaccination in patients with multiple sclerosis receiving immunomodulatory therapy. Eur J Neurol. 2018;25:527-534.

33. Bar-Or A, Calkwood JC, Chognot C, et al. Effect of ocrelizumab on vaccine responses in patients with multiple sclerosis: the VELOCE study. Neurology. 2020;95: e1999-e2008.

34. Kappos L, Mehling M, Arroyo R, et al. Randomized trial of vaccination in fingolimodtreated patients with multiple sclerosis. Neurology. 2015;84:872-879.

35. Apostolidis SA, Kakara M, Painter MM, et al. Cellular and humoral immune responses following SARS-CoV-2 mRNA vaccination in patients with multiple sclerosis on antiCD20 therapy. Mat Med. 2021;27:1990-2001.

36. Petrone L, Petruccioli E, Vanini V, et al. A whole blood test to measure SARS-CoV-2 specific response in COVID-19 patients. Clin Microbiol Infect. 2021;27:286.e7-286.e13.

37. Frampton JE. Ocrelizumab: first global approval. Drugs. 2017;77:1035-1041.

38. D'Abramo A, Vita S, Maffongelli G, et al. Prolonged and severe SARS-CoV-2 infection in patients under B-cell-depleting drug successfully treated: a tailored approach. Int J Infect Dis. 2021;107:247-250.

39. Oksbjerg NR, Nielsen SD, Blinkenberg M, Magyari M, Sellebjerg F. Anti-CD20 antibody therapy and risk of infection in patients with demyelinating diseases. Mult Scler Relat Disord. 2021;52:102988.

40. Iannetta M, Cesta N, Stingone C, et al. Mild clinical manifestations of SARS-CoV-2 related pneumonia in two patients with multiple sclerosis under treatment with ocrelizumab. Mult Scler Relat Disord. 2020;45:102442.

41. Zafranskaya M, Oschmann P, Engel R, et al. Interferon-beta therapy reduces CD4+ and CD8+ T-cell reactivity in multiple sclerosis. Immunology. 2007;121:29-39.

42. Comi G, Cook S, Giovannoni G, et al. Effect of cladribine tablets on lymphocyte reduction and repopulation dynamics in patients with relapsing multiple sclerosis. Mult Scler Relat Disord. 2019;29:168-174.

43. Goletti D, Lee MR, Wang JY, Walter N, Ottenhoff THM. Update on tuberculosis biomarkers: from correlates of risk, to correlates of active disease and of cure from disease. Respirology. 2018;23:455-466. 


\section{Neurology}

\section{Humoral- and T-Cell-Specific Immune Responses to SARS-CoV-2 mRNA Vaccination in Patients With MS Using Different Disease-Modifying Therapies \\ Carla Tortorella, Alessandra Aiello, Claudio Gasperini, et al.}

Neurology 2022;98;e541-e554 Published Online before print November 22, 2021

DOI 10.1212/WNL.0000000000013108

This information is current as of November 22, 2021

\section{Updated Information \& Services}

References

Citations

Subspecialty Collections

Permissions \& Licensing

Reprints including high resolution figures, can be found at: http://n.neurology.org/content/98/5/e541.full

This article cites 40 articles, 4 of which you can access for free at: http://n.neurology.org/content/98/5/e541.full\#ref-list-1

This article has been cited by 2 HighWire-hosted articles: http://n.neurology.org/content/98/5/e541.full\#\#otherarticles

This article, along with others on similar topics, appears in the following collection(s):

Autoimmune diseases

http://n.neurology.org/cgi/collection/autoimmune_diseases

Class III

http://n.neurology.org/cgi/collection/class_iii

COVID-19

http://n.neurology.org/cgi/collection/covid_19

Multiple sclerosis

http://n.neurology.org/cgi/collection/multiple_sclerosis

Information about reproducing this article in parts (figures,tables) or in its entirety can be found online at:

http://www.neurology.org/about/about_the_journal\#permissions

Information about ordering reprints can be found online:

http://n.neurology.org/subscribers/advertise

Neurology ${ }^{\circledR}$ is the official journal of the American Academy of Neurology. Published continuously since 1951, it is now a weekly with 48 issues per year. Copyright Copyright (C) 2021 The Author(s). Published by Wolters Kluwer Health, Inc. on behalf of the American Academy of Neurology.. All rights reserved. Print ISSN: 0028-3878. Online ISSN: 1526-632X.

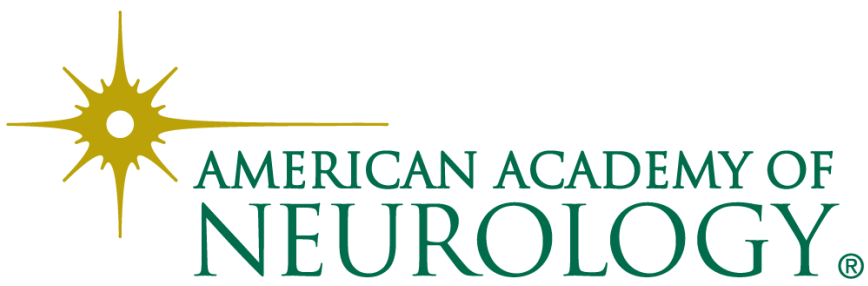

